\title{
Multistep oxidation of diethynyl oligophenylamine-bridged diruthenium and diiron complexes
}

Article

Accepted Version

Zhang, J., Guo, S.-Z., Don, Y.-B., Rao, L., Jin, Y., Yu, G.-A., Hartl, F. and Liu, S. H. (2017) Multistep oxidation of diethynyl oligophenylamine-bridged diruthenium and diiron complexes. Inorganic Chemistry, 56 (2). pp. 1001-1015. ISSN 0020-1669 doi: https://doi.org/10.1021/acs.inorgchem.6b02809 Available at https://centaur.reading.ac.uk/68545/

It is advisable to refer to the publisher's version if you intend to cite from the work. See Guidance on citing.

To link to this article DOI: http://dx.doi.org/10.1021/acs.inorgchem.6b02809

Publisher: American Chemical Society

All outputs in CentAUR are protected by Intellectual Property Rights law, including copyright law. Copyright and IPR is retained by the creators or other copyright holders. Terms and conditions for use of this material are defined in the End User Agreement.

www.reading.ac.uk/centaur

\section{CentAUR}


Central Archive at the University of Reading

Reading's research outputs online 


\title{
Multistep Oxidation of Diethynyl Oligophenylamine-Bridged ${ }_{2}$ Diruthenium and Diiron Complexes
}

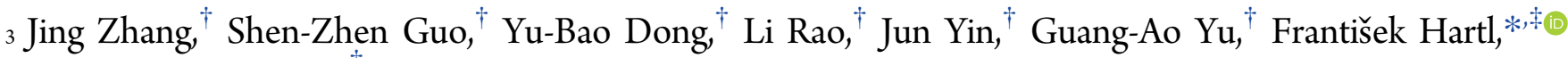 \\ 4 and Sheng Hua Liu* ${ }^{\dagger}$ \\ $5{ }^{\dagger}$ Key Laboratory of Pesticide and Chemical Biology, Ministry of Education, College of Chemistry, Central China Normal University, \\ 6 Wuhan 430079, P. R. China \\ $7{ }^{\ddagger}$ Department of Chemistry, University of Reading, Whiteknights, Reading RG6 6AD, U.K.
}

ABSTRACT: Homo-dinuclear nonlinear complexes $[\{\mathrm{M}(\mathrm{dppe})$ $\left.\mathrm{Cp} *\}_{2}\left\{\mu-(-\mathrm{C} \equiv \mathrm{C})_{2} \mathrm{X}\right\}\right]$ (dppe $=1,2$-bis(diphenylphosphino)ethane; $\mathrm{Cp}^{*}=\eta^{5}-\mathrm{C}_{5} \mathrm{Me}_{5} ; \mathrm{X}=$ triphenylamine (TPA), $\mathrm{M}=\mathrm{Ru}(\mathbf{1 a})$ and $\mathrm{Fe}$ (1b); X = N,N,N, $N^{\prime}$,-tetraphenylphenylene-1,4-diamine (TPPD), $\mathrm{M}=$ $\mathrm{Ru}(\mathbf{2 a})$ ) were prepared and characterized by ${ }^{1} \mathrm{H},{ }^{13} \mathrm{C}$, and ${ }^{31} \mathrm{P}$ NMR spectroscopy and single-crystal X-ray diffraction (1a, 2a). Attempts to prepare the di-iron analogue of $2 a$ were not successful. Experimental data obtained from cyclic voltammetry, square wave voltammetry, UVvis-NIR (NIR = near-infrared) spectro-electrochemistry, and very informative IR spectro-electrochemistry in the $\mathrm{C} \equiv \mathrm{C}$ stretching region, combined with density functional theory calculations, afford to make an emphasizing assessment of the close association between the metalethynyl termini and the oligophenylamine bridge core as well as their respective involvement in sequential one-electron oxidations of these

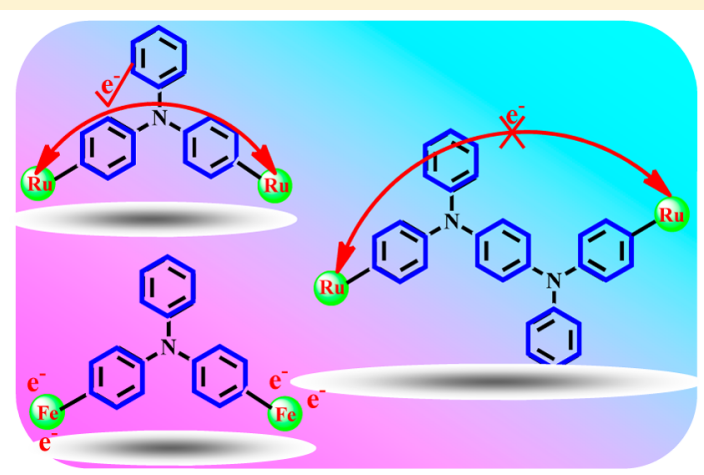
complexes. The anodic behavior of the homo-bimetallic complexes depends strongly both on the metal center and the length of the oligophenylamine bridge core. The poorly separated first two oxidations of di-iron complex $\mathbf{1 b}$ are localized on the electronically nearly independent Fe termini. In contrast, diruthenium complex 1a exhibits a significantly delocalized character and a marked electronic communication between the ruthenium centers through the diethynyl-TPA bridge. The rutheniumethynyl halves in 2a, separated by the doubly extended and more flexible TPPD bridge core, show a lower degree of electronic coupling, resulting in close-lying first two anodic waves and the NIR electronic absorption of $[2 \mathrm{a}]^{+}$with an indistinctive intervalence charge transfer character. Finally, the third anodic waves in the voltammetric responses of the homo-bimetallic complexes are associated with the concurrent exclusive oxidation of the TPA or TPPD bridge cores.

\section{INTRODUCTION}

32 In recent years mixed-valence (MV) states of binuclear 33 complexes have attracted considerable attention, ${ }^{1,2}$ providing 34 important model systems for intramolecular charge transfer 35 processes and offering broad prospects for building highly 36 functionalized molecules with interesting electronic and 37 optoelectronic properties essential for molecular scale electro38 active materials and devices. ${ }^{3-6}$ In this respect, numerous 39 studies focused in the past decades on rigid and $\pi$-conjugated 40 bridging ligands connecting two redox-active metallic termini, 41 as the simplest models for the electron-transfer phenomena in 42 the MV systems. ${ }^{7-10}$ Comprehensive studies have explored a 43 wide range of systems designed to provide some insight into 44 electron transfer over a long distance. ${ }^{11}$ However, increasing 45 the chain length to a modest degree decreased significantly 46 solubility of the prototypical $\pi$-conjugated systems in common 47 organic solvents, and the complexity of their syntheses 48 essentially arose. These factors present obstacles for the 49 relevant fundamental research and restrict the longitudinal 50 extension and processability in electronic devices. ${ }^{11}$ In this respect, continued search for novel or modified perspective 51 systems to eliminate the above-mentioned drawbacks is very 52 meaningful and challenging.

Triphenylamine (TPA) and other mono- and oligomeric 54 triarylamine derivatives have widely been used as selective one- 55 electron reductants, electrocatalysts, and hole-transporting 56 materials in organic optoelectronic devices, such as photo- 57 conductors, photorefractive materials, and organic light- 58 emitting devices. This is ascribed to their favorable redox 59 properties, with one or more readily accessible oxidations and 60 high stabilities of the corresponding radical cations with 61 appropriate substitution patterns. ${ }^{12-14}$ Moreover, TPA has 62 also been considered as an ideal redox center to study the 63 intermolecular electron transfer processes in MV systems. ${ }^{15-17} 64$ Despite the efforts, reports on mixed-valence systems featuring 65 the TPA unit as (a component of) a bridging ligand are 66 relatively limited in number compared with the $\pi$-conjugated 67

Received: November 23, 2016 
Chart 1. Studied Diethynyl Oligophenylamine-Bridged Homo-Bimetallic Ruthenium and Iron Complexes

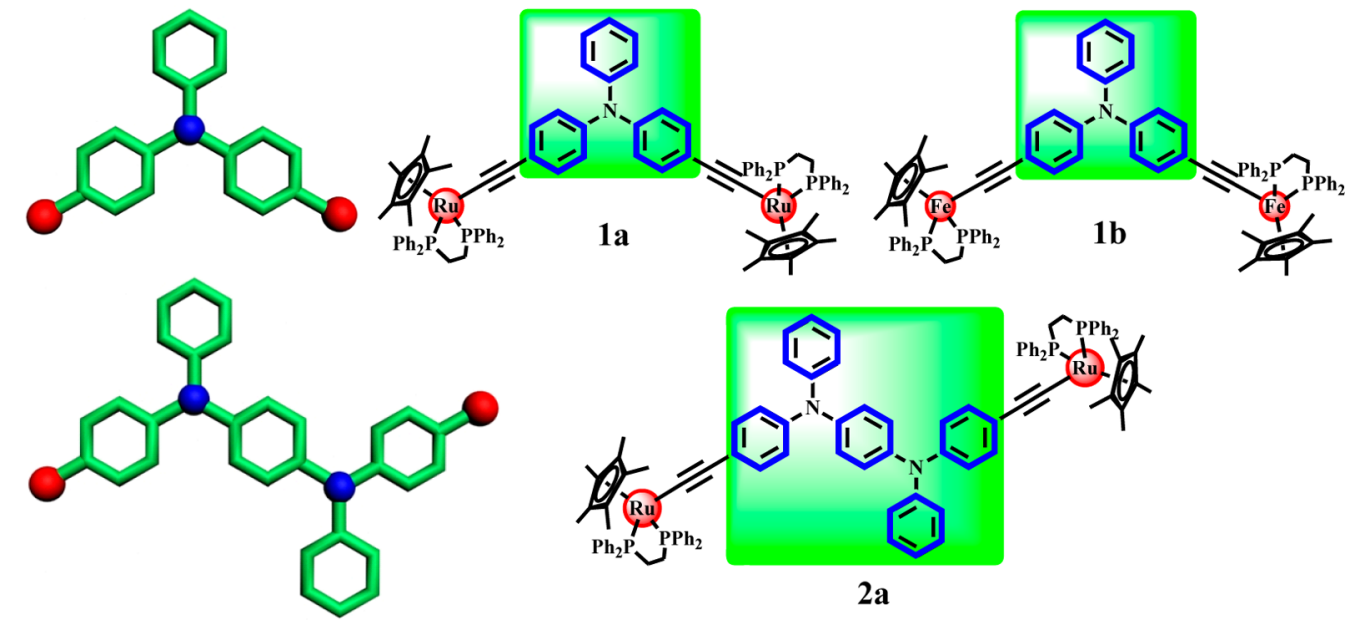

Scheme 1. General Synthetic Routes to Complexes 1a, 1b, and $2 a^{a}$

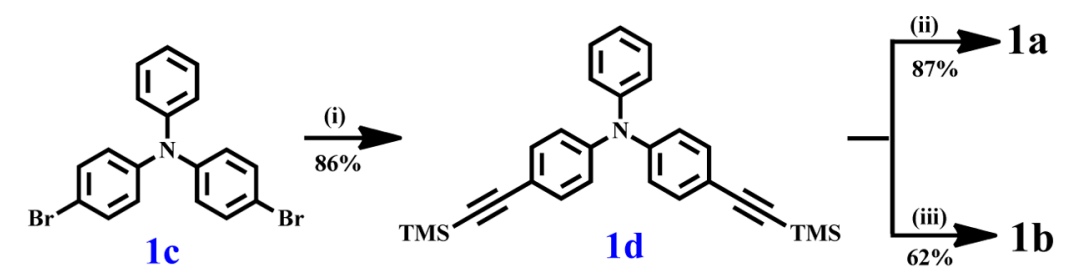

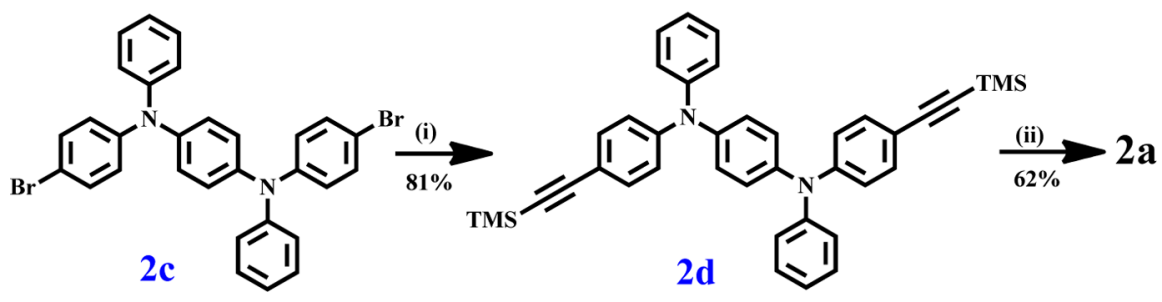

${ }^{a}$ Reagents and conditions: (i) $\left[\mathrm{Pd}\left(\mathrm{PPh}_{3}\right)_{4}\right], \mathrm{CuI}, \mathrm{Et}_{3} \mathrm{~N}$, TMSA, in THF; (ii) $[\mathrm{RuCl}(\mathrm{dppe}) \mathrm{Cp} *], \mathrm{KF}, \mathrm{MeOH} / \mathrm{THF}$; (iii) $\mathrm{K}_{2} \mathrm{CO}_{3}$ in $\mathrm{CH}_{3} \mathrm{OH}$, $\left[\mathrm{FeCl}(\right.$ dppe $\left.) \mathrm{Cp}^{*}\right], \mathrm{NaBPh}_{4}, t$-BuOK .

68 systems, $^{18}$ let alone a detailed discussion of their electronic 69 properties. $^{18 \mathrm{~d}}$ In another aspect, a nonrigid TPA-based 70 structure with appropriate substituents ${ }^{12-14}$ offers a viable 71 solution to the problem of poorly soluble elongated systems 72 and the difficulty in synthesizing large dendrimers. Notably, 73 Onitsuka and co-workers synthesized successfully a series of 74 ruthenium-acetylide dendrimers with the tris(475 ethynylphenyl)amine bridging ligand up to the second 76 generation by using a convergent method. ${ }^{18 \mathrm{i}}$ In this work we 77 focus on TPA and scarcely reported tetraphenylphenylenedi78 amine (TPPD) in the core of the diethynyl-terminated bridge. 79 The external "Ru(dppe)Cp*" and "Fe(dppe)Cp*" (dppe = 1,280 bis(diphenylphosphino)ethane; $\left.\mathrm{Cp}^{*}=\eta^{5}-\mathrm{C}_{5} \mathrm{Me}_{5}\right)$ units com81 pleting the studied homo-bimetallic chains (Chart 1) are 82 particularly suited as reference redox-active termini in 83 molecular wire models to study their MV properties, as 84 documented by the previously reported work. ${ }^{2 \mathrm{~d}-\mathrm{h}, 19}$ The 85 assembly of multiple redox-active components was anticipated 86 to exhibit peculiar electrochemical and photophysical proper87 ties. Hereinafter we detail our efforts to explore to which degree 88 the redox, spectroscopic, and bonding properties and electronic 89 communication in the investigated homo-bimetallic series are 90 affected by the varied combination of the oligophenylamine bridge core and the metal centers. The input data for the 91 discussion have been obtained by using controlled-potential 92 voltammetry and UV-vis-NIR/IR (NIR = near-infrared) 93 spectro-electrochemistry combined with density functional 94 theory (DFT) calculations.

\section{RESULTS AND DISCUSSION}

96

Syntheses and Characterization. The general synthetic 97 route to homo-dinuclear metal complexes $\mathbf{1 a}, \mathbf{1} \mathbf{b}$, and $\mathbf{2 a}$ is 98 outlined in Scheme 1. Bridge precursors 1d and 2d were $99 \mathrm{~s} 1$ obtained in yields higher than $80 \%$, having used $\mathrm{Pd} / \mathrm{Cu}-100$ catalyzed Sonogashira coupling reactions between 4-bromo- $N$ - 101 (4-bromophenyl)- $N$-phenylaniline (1c), $N^{1}, N^{4}$-bis(4-bromo- 102 phenyl)- $N^{1}, N^{4}$-diphenylbenzene-1,4-diamine (2c), and trime- 103 thylsilylacetylene (TMSA), respectively. Subsequently, the 104 trimethylsilyl (TMS) termini in compounds $\mathbf{1 d}$ and $\mathbf{2 d}$ were 105 deprotected with $\mathrm{KF}$ or $\mathrm{K}_{2} \mathrm{CO}_{3}$ to give the terminal bis(alkyne) 106 and then reacted with $\left[\mathrm{RuCl}(\mathrm{dppe}) \mathrm{Cp}^{*}\right]$ and $[\mathrm{FeCl}(\mathrm{dppe})-107$ $\left.\mathrm{Cp}^{*}\right]$ to obtain the corresponding target complexes 1a, 2a, and 108 1b, respectively. Unfortunately, deprotected 2d did not 109 coordinate to the $\mathrm{Fe}$ (dppe) $\mathrm{Cp}^{*}$ termini by this procedure, ${ }^{20} 110$ and the intended diethynyl-TPPD diiron complex (2b) was not 111 obtained. Notably, no obvious differences have been observed 112 
113 in comparative NMR responses of related diruthenium 114 complexes 1a and 2a, specifically, the dppe signals in the ${ }^{1} \mathrm{H}$ 115 and ${ }^{31} \mathrm{P}$ NMR spectra and the $\mathrm{Ru}-\mathrm{C} \equiv \mathrm{C}$ signals in the ${ }^{13} \mathrm{C}$ 116 NMR spectra.

117 X-ray Crystallography. The molecular structures of solid 118 1a and 2a were resolved by single-crystal X-ray diffraction. 119 Pertinent diffraction parameters are given in Table S1 (see the 120 Supporting Information). Important bond lengths ( $)$, bond 121 angles (deg), and $\mathrm{Ru} \cdots \mathrm{Ru}$ distances $(\AA)$ in the crystal structures 122 are collected in Table 1 . The structures of $1 \mathbf{a}$ and $\mathbf{2 a}$ feature

Table 1. Selected Bond Lengths (§̊), Angles (deg), and Inter-Ruthenium Distances $(\AA)$ in the Crystal Structures of Complexes 1a and $2 \mathrm{a}$

\begin{tabular}{cccc}
\multicolumn{5}{c}{ complex 1a } \\
\hline $\mathrm{Ru}(1)-\mathrm{C}(37)$ & $1.999(3)$ & $\mathrm{C}(43)-\mathrm{C}(44)$ & $1.378(4)$ \\
$\mathrm{Ru}(1)-\mathrm{P}(1,2)$ & $2.250(9), 2.258(8)$ & $\mathrm{C}(39)-\mathrm{C}(44)$ & $1.395(5)$ \\
$\mathrm{C}(37)-\mathrm{C}(38)$ & $1.209(4)$ & $\mathrm{C}(45)-\mathrm{C}(46)$ & $1.384(4)$ \\
$\mathrm{C}(38)-\mathrm{C}(39)$ & $1.436(4)$ & $\mathrm{C}(46)-\mathrm{C}(47)$ & $1.378(5)$ \\
$\mathrm{C}(39)-\mathrm{C}(40)$ & $1.401(5)$ & $\mathrm{C}(47)-\mathrm{C}(48)$ & $1.371(5)$ \\
$\mathrm{C}(40)-\mathrm{C}(41)$ & $1.382(4)$ & $\mathrm{N}(1)-\mathrm{C}(42)$ & $1.426(3)$ \\
$\mathrm{C}(41)-\mathrm{C}(42)$ & $1.387(4)$ & $\mathrm{N}(1)-\mathrm{C}(45)$ & $1.403(5)$ \\
$\mathrm{C}(42)-\mathrm{C}(43)$ & $1.391(4)$ & $\mathrm{Ru}(1) \ldots \mathrm{Ru}(2)$ & 14.19 \\
$\mathrm{P}(1)-\mathrm{Ru}(1)-\mathrm{P}(2)$ & $83.3(3)$ \\
$\mathrm{Ru}(1)-\mathrm{C}(37)-\mathrm{C}(38)$ & $174.9(3)$ \\
$\mathrm{C}(37)-\mathrm{C}(38)-\mathrm{C}(39)$ & $\mathrm{r}$ \\
\multicolumn{3}{c}{$175.6(3)$} \\
$\mathrm{Ru}(1)-\mathrm{C}(27)$ & $1.991(5)$ & $\mathrm{C}(36)-\mathrm{C}(37)$ & $1.343(2)$ \\
$\mathrm{Ru}(1)-\mathrm{P}(1,2)$ & $2.246(3), 2.248(3)$ & $\mathrm{C}(37)-\mathrm{C}(38)$ & $1.390(2)$ \\
$\mathrm{C}(27)-\mathrm{C}(28)$ & $1.214(9)$ & $\mathrm{C}(38)-\mathrm{C}(39)$ & $1.394(2)$ \\
$\mathrm{C}(28)-\mathrm{C}(29)$ & $1.448(7)$ & $\mathrm{C}(39)-\mathrm{C}(40)$ & $1.348(2)$ \\
$\mathrm{C}(29)-\mathrm{C}(30)$ & $1.375(9)$ & $\mathrm{C}(35)-\mathrm{C}(40)$ & $1.402(8)$ \\
$\mathrm{C}(30)-\mathrm{C}(31)$ & $1.360(8)$ & $\mathrm{C}(41)-\mathrm{C}(42)$ & $1.363(9)$ \\
$\mathrm{C}(31)-\mathrm{C}(32)$ & $1.390(9)$ & $\mathrm{C}(42)-\mathrm{C}(43)$ & $1.393(9)$ \\
$\mathrm{C}(32)-\mathrm{C}(33)$ & $1.378(9)$ & $\mathrm{C}(41)-\mathrm{C}(43)$ & $1.390(8)$ \\
$\mathrm{C}(33)-\mathrm{C}(34)$ & $1.389(7)$ & $\mathrm{N}(1)-\mathrm{C}(32)$ & $1.428(5)$ \\
$\mathrm{C}(29)-\mathrm{C}(34)$ & $1.392(2)$ & $\mathrm{N}(1)-\mathrm{C}(41)$ & $1.424(6)$ \\
$\mathrm{C}(35)-\mathrm{C}(36)$ & $1.392(2)$ & $\mathrm{Ru}(1) \cdots \mathrm{Ru}(2)$ & 20.68 \\
$\mathrm{P}(1)-\mathrm{Ru}(1)-\mathrm{P}(2)$ & $84.4(3)$ \\
$\mathrm{Ru}(1)-\mathrm{C}(37)-\mathrm{C}(38)$ & $178.5(3)$ \\
$\mathrm{C}(37)-\mathrm{C}(38)-\mathrm{C}(39)$ & $176.1(3)$ \\
& & \multicolumn{2}{c}{}
\end{tabular}

approximately linear $\mathrm{Ru}-\mathrm{C} \equiv \mathrm{C}-\mathrm{C}$ moieties, the pairs of $\mathrm{Ru}-123$ $\mathrm{C} \equiv \mathrm{C}$ and $\mathrm{C} \equiv \mathrm{C}-\mathrm{C}$ angles being $174.9^{\circ}, 175.6^{\circ}$ and $178.5^{\circ}, 124$ $176.1^{\circ}$, respectively. As seen in Figure 1 and Figure S1(A) $125 \mathrm{fl}$ (Supporting Information), the crystallographic analysis mani- 126 fests typical pseudo-octahedral geometry around the ruthenium 127 centers. The $\mathrm{C} \equiv \mathrm{C}$ bond lengths [1.209 $\AA$ (1a) and $1.214 \AA{ }_{128}$ (2a)] comply with a carbon-carbon triple bond, and the 129 bonding parameters of the $\mathrm{Ru}(\mathrm{dppe}) \mathrm{Cp}^{*}$ group, including the 130 $\mathrm{Ru}-\mathrm{C}$ and $\mathrm{Ru}-\mathrm{P}$ distances and $\mathrm{P}-\mathrm{Ru}-\mathrm{P}$ angles, compare well 131 with the data reported for a range of similar systems. ${ }^{21,22} 132$ Elongation of the bridging ligand core from monoamine (TPA) 133 in $\mathbf{1 a}$ to diamine (TPPD) in $\mathbf{2 a}$ caused the $\mathrm{Ru}(1) \cdots \mathrm{Ru}(2) 134$ distance to increase considerably from 14.19 to $20.68 \AA$. These 135 data are consistent with the corresponding calculated results 136 presented hereinafter.

Some additional interesting features can be found in the 138 crystal packing (Figure S1(B)). Complex 2a shows typical 139 lamellar packing characteristics with the parallel arrangements 140 of the bridge and metallic termini in each layer from the side 141 view of the lamellar structure, the benzene rings 1, 3 and 2, 4 of 142 the diamine bridge core (Figure S1(B)) being oriented in 143 opposite directions and arranged in parallel with each other. 144

Electrochemical Properties. The anodic behavior of 145 complexes $\mathbf{1 a}, \mathbf{1 b}$, and $\mathbf{2 a}$ was investigated by cyclic 146 voltammetry (CV) and square-wave voltammetry (SWV) in 147 deaerated dichloromethane containing $1 \times 10^{-1} \mathrm{M} n-\mathrm{Bu}_{4} \mathrm{NPF}_{6} 148$ as the supporting electrolyte (Figure 2). The TMS-terminated $149 \mathrm{f} 2$ precursors 1d and 2d (Scheme 1) were also studied for 150 comparison (see Supporting Information, Figure S2). The 151 relevant electrochemical data are summarized in Table $2 . \quad 152$ t2

Complexes $\mathbf{1 a}$ and $\mathbf{1 b}$ exhibit three successive oxidation 153 steps. The anodic behavior of $2 \mathrm{a}$ is more complex, and only the 154 first four anodic processes were investigated. Comparing the 155 electrochemical behavior of diruthenium complexes 1a and 2a, 156 the potentials of their first three anodic steps $\left(E_{1 / 2}(1,2,3)\right)$ are 157 similar. The main difference arises in the wave splitting 158 $\Delta E_{1 / 2}(1-2)$ and the thermodynamic stability (comproportio- 159 nation) constant $K_{\mathrm{c}}$ of $[\mathbf{2 a}]^{+}$, which is considerably smaller than 160 that determined for $[\mathbf{1 a}]^{+}$(Table 2 ). This result has likely its 161 origin in the extended bridge core in $\mathbf{2 a}$ and limited electronic 162 communication between two redox active $\mathrm{Ru}-\mathrm{C} \equiv \mathrm{C}$ units, 163 resembling in this respect an earlier reported series of 164

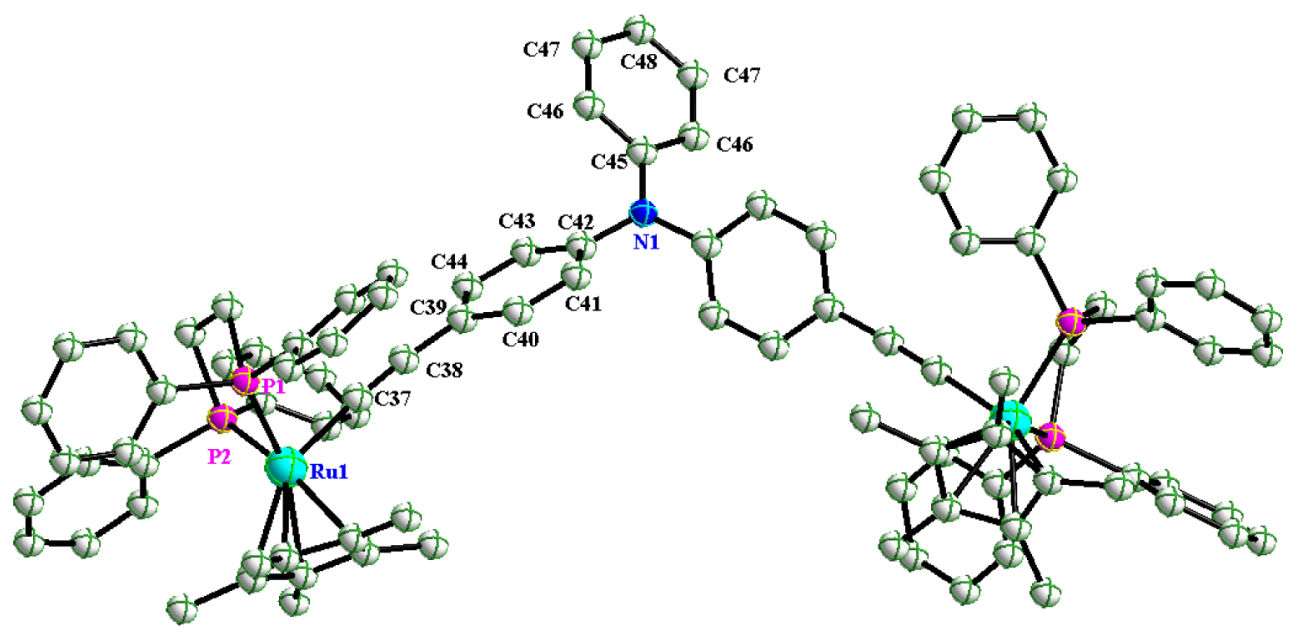

Figure 1. X-ray crystal structure of 1a shown with thermal ellipsoids at the $50 \%$ probability level. Hydrogen atoms were omitted for clarity. Full crystallographic details are given in Supporting Information. CCDC No. 1435472. 

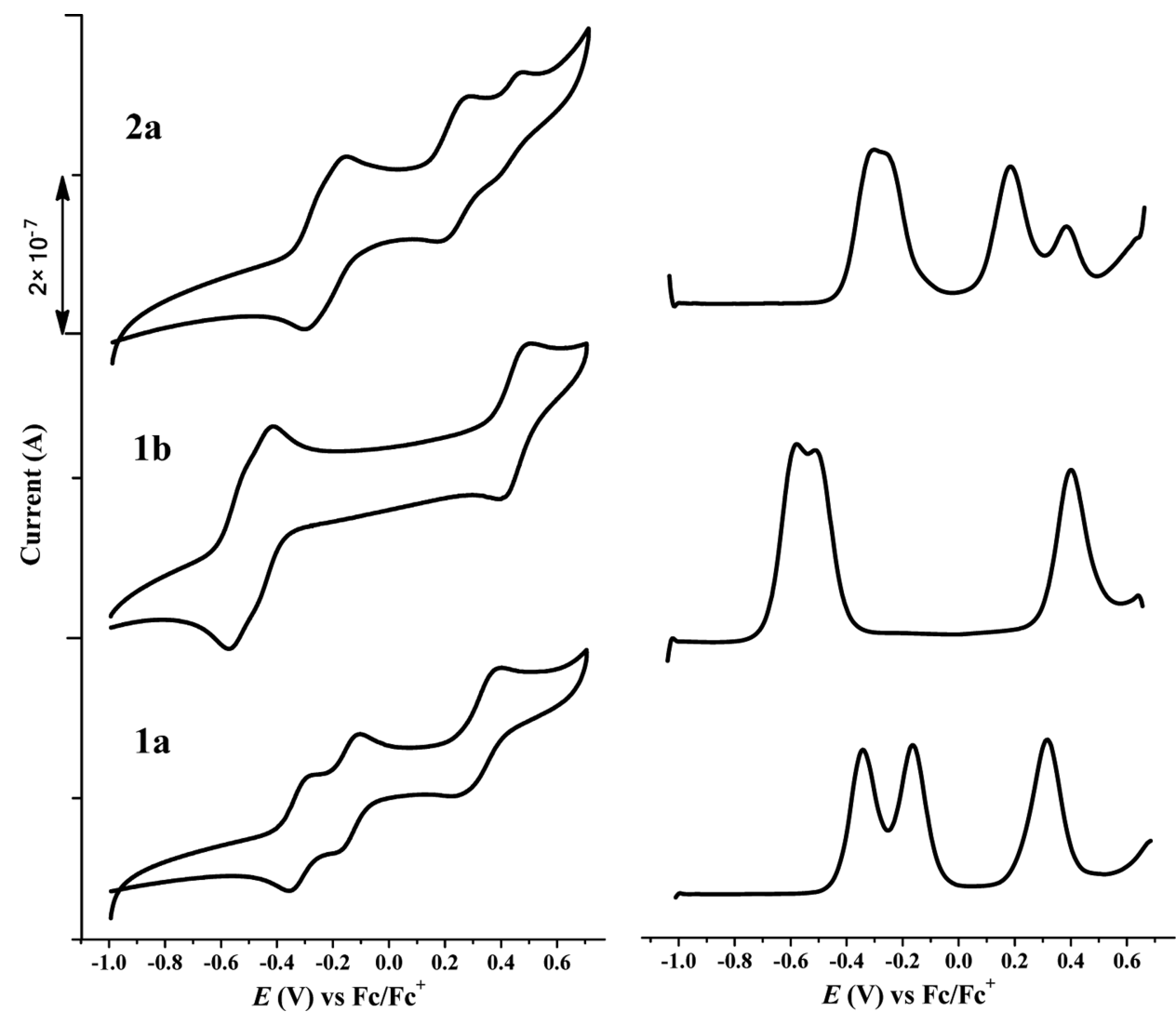

Figure 2. (left) $\mathrm{CV}$ of complexes $\mathbf{1 a}, \mathbf{1} \mathbf{b}$, and $\mathbf{2} \mathbf{a}$ in $\mathrm{CH}_{2} \mathrm{Cl}_{2} / n-\mathrm{Bu}_{4} \mathrm{NPF}_{6}$ at $v=50 \mathrm{mV} \mathrm{s}^{-1}$. (right) Corresponding SWV of complexes $\mathbf{1 a}$, $\mathbf{1 b}$, and $\mathbf{2 a}$ at $f=10 \mathrm{~Hz}$ and $t_{\mathrm{p}}=25 \mathrm{mV}$.

Table 2. Electrochemical Data for Complexes 1a, 1b, and 2a, TMS-Terminated Reference Compounds 1d and 2d, a Dinuclear Vinyl-Ruthenium Complex Related to 1a, and Reference Phenylamines ${ }^{a}$

\begin{tabular}{|c|c|c|c|c|c|c|}
\hline compound & $E_{1 / 2}(1)(\mathrm{V})$ & $E_{1 / 2}(2)(\mathrm{V})$ & $E_{1 / 2}(3)(\mathrm{V})$ & $E_{1 / 2}(4)(\mathrm{V})$ & $\Delta E_{1 / 2}(1-2)(\mathrm{mV})$ & $K_{\mathrm{c}}^{b}$ \\
\hline 1a & -0.36 & -0.18 & 0.30 & & 180 & $1.1 \times 10^{3}$ \\
\hline $\mathbf{R u}-$ vinyl $^{c}$ & -0.17 & 0.15 & 0.59 & & 320 & $3.8 \times 10^{5}$ \\
\hline $1 b$ & -0.56 & -0.50 & 0.41 & & 60 & 10 \\
\hline $1 \mathrm{~d}$ & 0.66 & & & & & \\
\hline $\mathbf{T P A}^{d}$ & $0.70^{e f f}$ & & & & & \\
\hline $2 a$ & -0.31 & -0.26 & 0.19 & 0.39 & 50 & 7 \\
\hline $2 d$ & 0.21 & 0.68 & & & & \\
\hline TPPD $^{d}$ & $0.14^{f}$ & 0.63 & & & & \\
\hline
\end{tabular}

${ }^{a_{T}}$ The anodic potentials are referenced against the standard ferrocene/ferrocenium $\left(\mathrm{Fc} / \mathrm{Fc}^{+}\right)$redox couple. ${ }^{b}$ The comproportionation constants $K_{\mathrm{c}}$ were estimated using the expression $K_{\mathrm{c}}=\exp (\Delta E / 25.69 \mathrm{mV})$ at $298 \mathrm{~K}$, with input data recorded at $v=50 \mathrm{mV} \mathrm{s}^{-1} .{ }^{c}\left[\left\{\mathrm{Cl}(\mathrm{CO})(\mathrm{PiPr})_{2} \mathrm{Ru}-\mathrm{CH}=\right.\right.$ $\left.\mathrm{CH}-\mathrm{C}_{6} \mathrm{H}_{4}-\right\}_{2} \mathrm{~N}-\mathrm{C}_{6} \mathrm{H}_{4} \mathrm{OCH}_{3}$. ${ }^{18 \mathrm{~d}}{ }^{d}$ Reference $18 \mathrm{f}$. ${ }^{e}$ Irreversible anodic peak potential. ${ }^{f}$ Potential determined against an $\mathrm{Ag} / \mathrm{AgCl} \mathrm{reference}$ electrode; $E_{1 / 2}\left(\mathrm{Fc} / \mathrm{Fc}^{+}\right)=+0.43 \mathrm{~V}$ versus $\mathrm{Ag} / \mathrm{AgCl}$.

165 oligothiophene-bridged diruthenium diethynyl complexes. ${ }^{2 \mathrm{i}}$ 166 The additional fourth anodic wave of $\mathbf{2 a}$ at a higher potential 167 can safely be ascribed to the second oxidation of the diamine 168 core, based on comparison with the anodic potentials of the 169 TMS-terminated diethynyl TPPD reference compound $\mathbf{2 d}$.

170 The obvious difference in the composition of $\mathbf{1 a}$ and $\mathbf{1 b}$ is 171 the metallic redox center. Interestingly, the replacement of 172 ruthenium in $\mathbf{1 a}$ with iron in $\mathbf{1} \mathbf{b}$ resulted in a slightly negative 173 shift of the first anodic wave (at $E_{1 / 2}(1)$ ) and significantly 174 decreased comproportionation constant $K_{\mathrm{c}}$ (Table 2). It will be 175 shown in the spectro-electrochemical section that the formally $176 \mathrm{Fe}$ (II) centers in the terminal positions of $\mathbf{1 b}$ oxidize in a more 177 localized fashion compared to the $\mathrm{Ru}$ (II) derivative, 1a, as also 178 encountered in the literature for related compounds. ${ }^{3 c, 8 b, 18 h, 23}$
Accordingly, the two formally $\mathrm{Fe}(\mathrm{II})$ centers in $\mathbf{1 b} 179$ communicate poorly through the twisted ethynyl-phenyl- 180 ene-N-phenylene-ethynyl bridge, in line with the small 181 $\Delta E_{1 / 2}(1-2)$ and $K_{c}$ values for $[\mathbf{1 b}]^{+}$. Consequently, it was 182 hardly possible to record IR and UV-vis-NIR spectra of 183 "pure" $[\mathbf{1 b}]^{+}$in the course of the corresponding spectro- 184 electrochemical experiments described in the following section. 185 A less severe restriction applies in this regard for $[\mathbf{2 a}]^{+} . \quad 186$

A significantly greater involvement of the TPA core in the 187 electrochemical oxidation has been reported ${ }^{18 \mathrm{~d}}$ for a bridged 188 dinuclear vinyl-ruthenium complex, causing a stronger 189 electronic interaction between the ruthenium-vinyl linker 190 subunits in the corresponding one-electron oxidized cation and 191 a larger $K_{c}$ value (Table 2). The different auxiliary ligands at the 192 

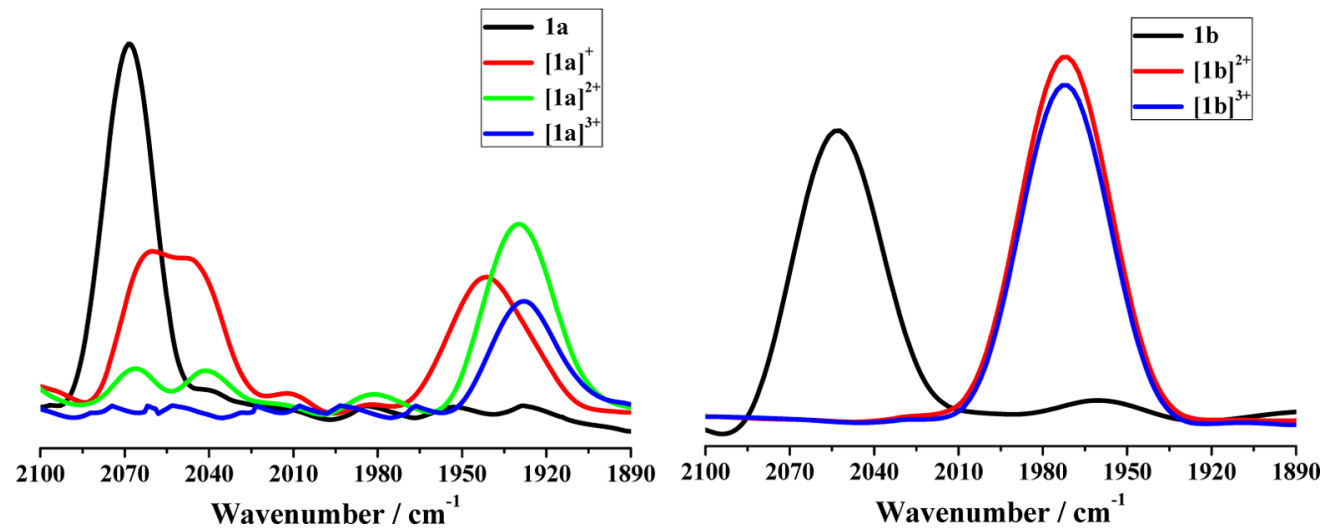

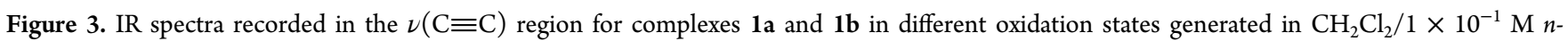
$\mathrm{Bu}_{4} \mathrm{NPF}_{6}$ at $298 \mathrm{~K}$ within an OTTLE cell. For the chemical oxidation of $\mathbf{1 b}$ to [1 $\left.\mathbf{b}\right]^{+}$see Supporting Information, Figure S6.

193 ruthenium center, specifically, trans- $\mathrm{RuCl}(\mathrm{CO})\left\{\mathrm{P}(i-\mathrm{Pr})_{3}\right\}_{2}$, also 194 play a role in the control of the electronic conjugation between 195 the TPA bridge core and the ruthenium-linker (vinyl vs 196 ethynyl) subunits. For example, smaller differences in the 197 anodic behavior exist between TPA-based mono- and trinuclear 198 vinyl-ruthenium ${ }^{18 \mathrm{~d}}$ and ethynyl-ruthenium ${ }^{24}$ complexes with $^{2}$ 199 similar ruthenium coordination sites.

200 IR and UV-vis-NIR Spectro-Electrochemistry. IR and 201 UV-vis-NIR spectro-electrochemical studies were undertaken 202 to get insight into the nature of the physical and electronic 203 structures in different oxidation states within the investigated 204 three redox series.

205 The IR spectra of neutral complexes $\mathbf{1 a}, \mathbf{1} \mathbf{b}$, and $\mathbf{2 a}$ are 206 characterized by a strong single $\nu(\mathrm{C} \equiv \mathrm{C})$ band (Figure 3, 207 Figure S3 (Supporting Information), and Table 3). By contrast,

Table 3. Spectro-Electrochemically Determined $\nu(\mathrm{C} \equiv \mathrm{C})$ Wavenumbers $\left(\mathrm{cm}^{-1}\right)$ for $[1 \mathrm{a}]^{n+},[1 \mathrm{~b}]^{n+},[1 \mathrm{~d}]^{n+}$ and $[2 \mathrm{a}]^{n+}$, $[2 \mathrm{~d}]^{n+}$

\begin{tabular}{crlrrr} 
complex & $n=0$ & \multicolumn{1}{c}{$n=1$} & $n=2$ & $n=3$ & $n=4$ \\
{$[\mathbf{1 a}]^{n+}$} & 2068 & $2059(\mathrm{~m}), 2046(\mathrm{~m})$, & 1930 & $1928(\mathrm{w}-$ & \\
& $(\mathrm{s})$ & $1941(\mathrm{~m})$ & $(\mathrm{m})$ & $\mathrm{m})$ & \\
{$[\mathbf{1 b}]^{n+}$} & 2052 & $a$ & 1972 & $1972(\mathrm{~s})$ & \\
& $(\mathrm{s})$ & & $(\mathrm{s})$ & & \\
{$[\mathbf{1 d}]^{n+}$} & 2065 & 2065 & & & \\
{$[\mathbf{2 a}]^{n+}$} & 2068 & $2066,1935^{b}$ & 1934 & $1933(\mathrm{w})$ & $c$ \\
& $(\mathrm{~s})$ & & $(\mathrm{s})$ & & \\
{$[\mathbf{2 d}]^{n+}$} & 2066 & $2066(\mathrm{~m})$ & 2066 & & \\
& $(\mathrm{~m})$ & & $(\mathrm{s})$ & &
\end{tabular}

${ }^{a_{T}}$ The $\nu(\mathrm{C} \equiv \mathrm{C})$ absorption of $[\mathbf{1 b}]^{+}$is not reported due to the small $K_{\mathrm{c}}$ value and a low conversion evidenced by UV-vis-NIR spectroscopy (Supporting Information, Figure S6). ${ }^{b}$ This absorption does not correspond to the pure form of $[2 \mathbf{a}]^{+}$due to small $K_{c}$ but to the maximum conversion reached by electrochemical oxidation of $\mathbf{2 a}$ determined by parallel UV-vis-NIR monitoring (Supporting Information, Figure $\mathrm{S} 12) .{ }^{c}$ No $\nu(\mathrm{C} \equiv \mathrm{C})$ band perceptible.

208 the $\nu(\mathrm{C} \equiv \mathrm{C})$ pattern of one-electron-oxidized $[\mathbf{1 a}]^{+}$is more 209 complex, consisting of a strongly shifted, fairly broad, and 210 slightly asymmetric absorption band at $1941 \mathrm{~cm}^{-1}$ and two 211 overlapping $\nu(\mathrm{C} \equiv \mathrm{C})$ bands at 2059 and $2046 \mathrm{~cm}^{-1}$, that is, 212 near the absorption of parent $1 \mathrm{a}$ at $2068 \mathrm{~cm}^{-1}$. These spectral 213 changes comply with the presence of a symmetry-broken 214 radical cation $[\mathbf{1 a}]^{+}$on the time scale of IR spectroscopy $(1 \times$ $21510^{-11}$ to $1 \times 10^{-12} \mathrm{~s}$ ), existing in different conformations 216 (rotamers $)^{25}$ with slightly different participation of the individual ethynyl-ruthenium moieties in the oxidation 217 process.

The second anodic step toward $[\mathbf{1} \mathbf{a}]^{2+}$ led to the 219 disappearance of both $\nu(\mathrm{C} \equiv \mathrm{C})$ bands close to the wave- 220 number of the neutral parent state, while a new single band at 221 $1930 \mathrm{~cm}^{-1}$ gained intensity. This behavior suggests the 222 complete oxidation of both $\mathrm{Ru}-\mathrm{C} \equiv \mathrm{C}$ centers in $[\mathbf{1 a}]^{2+} \cdot 223$ Importantly, no prominent low-energy shift of the $\nu(\mathrm{C} \equiv \mathrm{C}) 224$ mode was observed for the subsequent anodic generation of the 225 tricationic product $[\mathbf{1 a}]^{3+}$, characterized by a single absorption 226 band marking a symmetric electronic structure. The very little 227 $\nu(\mathrm{C} \equiv \mathrm{C})$ shift compares well with the invariable $\nu(\mathrm{C} \equiv \mathrm{C}) 228$ wavenumber encountered for the TMS-terminated diethynyl 229 TPA reference $[\mathbf{1 d}]$ and its monocation (Supporting 230 Information, Figure S4), suggesting the dominantly TPA- 231 localized one-electron oxidation of $[\mathbf{1 a}]^{2+}$. 232

The anodic conversion of $\mathbf{2 a}$ to $[\mathbf{2} \mathbf{a}]^{2+}$ was marked by 233 gradual disappearance of the parent $\nu(\mathrm{C} \equiv \mathrm{C})$ absorption at 234 $2068 \mathrm{~cm}^{-1}$ and the growth of a new absorption band at 1934235 $\mathrm{cm}^{-1}$ belonging to the dication (Supporting Information, 236 Figure S3). The red shift of $134 \mathrm{~cm}^{-1}$ is close to that of 138237 $\mathrm{cm}^{-1}$ observed for the oxidation of 1a to $[\mathbf{1 a}]^{2+}$ (Table 3 ), 238 indicating comparable participation of the ethynyl linkers in the 239 oxidation of $2 \mathrm{a}$ to the symmetric dication, in line with the 240 theoretical description (see below). The small separation of the 241 first two anodic waves of $\mathbf{2 a}$ implies that singly oxidized $[\mathbf{2 a}]^{+} 242$ can hardly be observed in the pure form. The IR spectrum in 243 Figure S3 corresponding to the redox equilibrium with the 244 highest concentration of $[\mathbf{2 a}]^{+}$was selected with the aid of the 245 characteristic NIR electronic absorption of the monocation (see 246 below) simultaneously monitored in the course of the careful 247 anodic electrolysis within the OTTLE cell. It can safely be 248 concluded that $[\mathbf{2 a}]^{+}$exists only in a single conformation 249 detectable on the time scale inherent to IR spectroscopy, 250 differently from $[\mathbf{1 a}]^{+}$(see above). The IR $\nu(\mathrm{C} \equiv \mathrm{C}) 251$ absorption of $[\mathbf{2 a}]^{+}$overlaps with those of parent $\mathbf{2 a}$ and 252 ultimately $[\mathbf{2 a}]^{2+}$ (Table 3 ), rendering the monocation with 253 weak electronic coupling between the $\mathrm{Ru}-\mathrm{C} \equiv \mathrm{C}$ termini not 254 exceeding that in $[\mathbf{l a}]^{+}$, in line with the corresponding $\mathrm{CV} 255$ responses (Table 2).

The third anodic step producing stable $[\mathbf{2 a}]^{3+}$ was not 257 accompanied by any $\nu(\mathrm{C} \equiv \mathrm{C})$ shift, causing merely a strongly 258 diminished intensity of the $\nu(\mathrm{C} \equiv \mathrm{C})$ band at $1934 \mathrm{~cm}^{-1} 259$ (Figure S3). This behavior reflects the dominant oxidation of 260 the TPPD bridge core in $[\mathbf{2 a}]^{2+}$ to the corresponding radical 261 cation. This assignment is supported by the invariable $\nu(\mathrm{C} \equiv \mathrm{C}) 262$ 
263 wavenumber in the TMS-terminated reference redox series $264[2 \mathbf{d}]^{n+}(n=0,1,2)$; see Table 3 and Supporting Information, 265 Figure S4.

266 The poorly resolved first two anodic steps of $\mathbf{1 b}$ (Table 2 and 267 Figure 2) resemble the oxidation of $2 \mathrm{a}$. We note that the $\nu(\mathrm{C} \equiv$ $268 \mathrm{C})$ shift induced by the oxidation of $\mathbf{1 b}$ to $\mathbf{1 b}^{2+}$ is merely 80 $269 \mathrm{~cm}^{-1}$ compared to $134 \mathrm{~cm}^{-1}$ for $2 \mathrm{a} \rightarrow[2 \mathrm{a}]^{2+}$, and $138 \mathrm{~cm}^{-1}$ for $270 \mathbf{1 a} \rightarrow[\mathbf{1 a}]^{2+}$ featuring the same molecular bridge (Table 3 ). This 271 difference points to significantly more Fe-centered oxidation of 272 the $\mathrm{Fe}-\mathrm{C} \equiv \mathrm{C}$ termini, as also confirmed by DFT calculations 273 (see below). The electronic interaction between the Fe centers 274 in $[\mathbf{1 b}]^{+}$through the TPA core becomes strongly limited, 275 resulting in dominant disproportionation of the monocation to $276 \mathbf{1 b}$ and $[\mathbf{1 b}]^{2+}$. Therefore, $[\mathbf{1 b}]^{+}$is hardly detectable by IR 277 spectroscopy (Table 3 and Supporting Information, Figures S5 278 and S6), and only the characteristic NIR absorption 279 (Supporting Information, Figure S6) reveals its presence. The 280 negligible change in the $\nu(\mathrm{C} \equiv \mathrm{C})$ wavenumber accompanying 281 the third anodic step producing $[\mathbf{1 b}]^{3+}$ resembles the formation 282 of $[\mathbf{1 a}]^{3+}$ (Figure 3 ), both bearing the TPA-core oxidation 283 characteristics.

284 The UV-vis-NIR spectra of complexes $\mathbf{1 a}, \mathbf{1} \mathbf{b}$, and $\mathbf{2} \mathbf{a}$ and 285 TMS-terminated bridges $\mathbf{1 d}$ and $\mathbf{2 d}$ in the different oxidation 286 states were recorded by using the spectro-electrochemical

287 monitoring or stepwise chemical oxidation, as shown in Figures 2884 and 5 and Supporting Information, Figures S7-S12. The 289 relevant data are collected in Table 4.
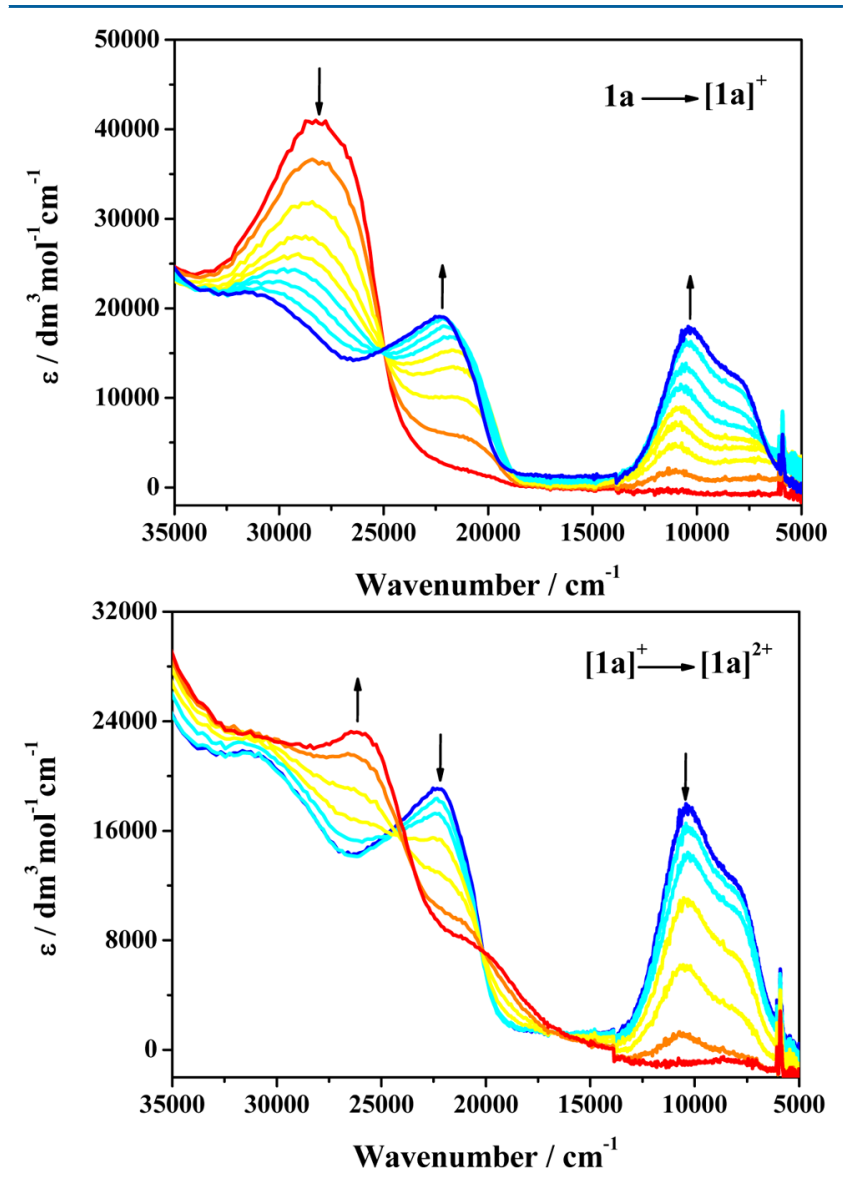

Figure 4. UV-vis-NIR spectral changes recorded during the oxidation of complex 1a to $[\mathbf{1 a}]^{+}$(top) and $[\mathbf{1 a}]^{2+}$ (bottom) in $\mathrm{CH}_{2} \mathrm{Cl}_{2} / 1 \times 10^{-1} \mathrm{M} \mathrm{n}$ - $\mathrm{Bu}_{4} \mathrm{NPF}_{6}$ at $298 \mathrm{~K}$ within an OTTLE cell.

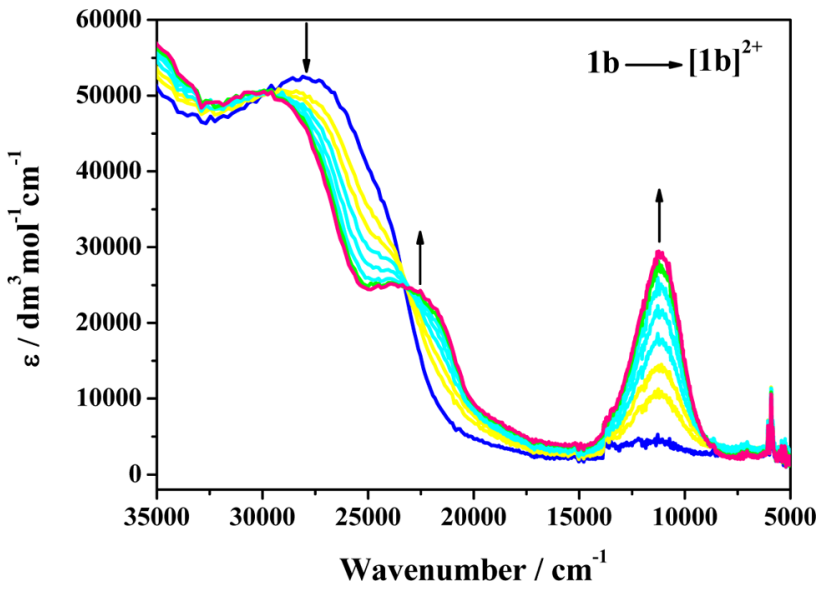

Figure 5. UV-vis-NIR spectral changes recorded during the oxidation of complex $\mathbf{1 b}$ to $[\mathbf{1 b}]^{2+}$ in $\mathrm{CH}_{2} \mathrm{Cl}_{2} / 1 \times 10^{-1} \mathrm{M} n$ $\mathrm{Bu}_{4} \mathrm{NPF}_{6}$ at $298 \mathrm{~K}$ within an OTTLE cell.

Table 4. UV-Vis-NIR Electronic Absorption of Complexes 1a, 1b, 1d, 2a, 2d, and Their Oxidized Forms in Dichloromethane $/ n-\mathrm{Bu}_{4} \mathrm{NPF}_{6}$

\begin{tabular}{ll} 
complex & \multicolumn{1}{c}{$\tilde{v}_{\max }\left(\mathrm{cm}^{-1}\right)\left(\varepsilon_{\max }\left(\mathrm{dm}^{3} \mathrm{~mol}^{-1} \mathrm{~cm}^{-1}\right)\right)$} \\
$\mathbf{1 a}$ & $28100(41300)$ \\
{$[\mathbf{1 a}]^{+}$} & $22200(19500), 10200(18100), 7800(12400)$ \\
{$[\mathbf{1 a}]^{2+}$} & $26000(23300), 20500(7600)$ \\
{$[\mathbf{1 a}]^{3+}$} & $23800(21900), 8300(10400)$ \\
$\mathbf{1 b}$ & $27500(52700)$ \\
{$[\mathbf{1 b}]^{+}$} & $a$ \\
{$[\mathbf{1 b}]^{2+}$} & $29600(50800), 22500(24700), 11200(29400)$ \\
{$[\mathbf{1 b}]^{3+}$} & $16800(32000), 9700(19000)$ \\
$\mathbf{1 d}$ & $41400(28600), 28500(40700)$ \\
{$[\mathbf{1 d}]^{+}$} & $13500(12200)$ \\
$\mathbf{2 a}$ & $29200(56600)$ \\
{$[\mathbf{2 a}]^{+b}$} & $30400,21600,10300,8400 \mathrm{sh}$ \\
{$[\mathbf{2 a}]^{2+}$} & $29800(44700), 22000(8500)$ \\
{$[\mathbf{2 a}]^{3+}$} & $23900(22700), 8700(22200)$ \\
$\mathbf{2 d}$ & $29600(43200)$ \\
{$[\mathbf{2 d}]^{+}$} & $23400(23600), 10400(19100), 8100(12400)$ \\
{$[\mathbf{2 d}]^{2+}$} & $38600(28300), 13900(44800)$
\end{tabular}

${ }^{a}$ Detectable by an unresolved weak NIR absorption between 10000 and $4000 \mathrm{~cm}^{-1}$ (see Supporting Information, Figure S6). ${ }^{b}$ Molar absorptivity not reported.

The diethynyl-TPA complex 1a exhibits a pronounced 290 broad absorption band at $\sim 2.8 \times 10^{4} \mathrm{~cm}^{-1}$, most likely 291 stemming from the $\pi \rightarrow \pi^{*}$ intraligand transition with some 292 metal-to-ligand charge transfer contribution, in line with the 293 reported similar systems. ${ }^{26-28}$ The smooth oxidation of neutral 294 $\mathbf{1 a}$ to $[\mathbf{1 a}]^{+}$conformers leads to the appearance of new intense 295 visible and NIR absorptions and strongly diminished parent UV 296 absorption (Figure 4, top). The asymmetric NIR absorption of 297 $[\mathbf{1 a}]^{+}$corresponds to an overlap of two sub-bands obtained by 298 deconvolution of the Gaussian function (Supporting Informa- 299 tion, Figure S9 and Table S2). On further oxidation to 300 dicationic species $[\mathbf{1 a}]^{2+}$, the characteristic NIR absorption of 301 $[\mathbf{1 a}]^{+}$gradually disappeared (Figure 4, bottom). The final, well- 302 separated anodic step producing $[\mathbf{1 a}]^{3+}$ led to appearance of a 303 new NIR absorption band below $1 \times 10^{4} \mathrm{~cm}^{-1}$ (Figure S7) 304 resembling the electronic absorption of oxidized reference 305 $[\mathbf{1 d}]^{+}$at $1.35 \times 10^{4} \mathrm{~cm}^{-1}$ (Figure S10) and, therefore, 306 belonging to the TPA radical cation. ${ }^{29}$ It has to be considered 307 


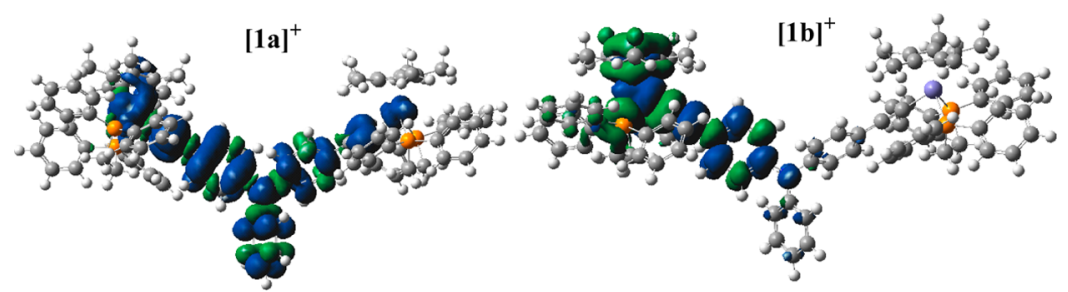

$0.25 / 0.22 / 0.39 / 0.05 / 0.03$

$1.39 / 0 / 0.01 / 0 / 0$

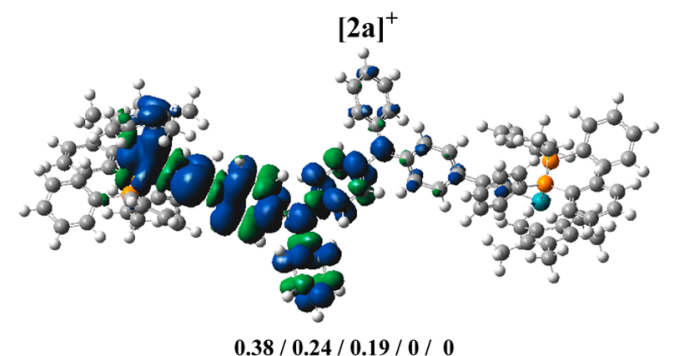

Figure 6. Calculated spin density distribution in $[\mathbf{1 a}]^{+}$and $[\mathbf{2 a}]^{+}(\mathrm{Ru} / \mathrm{C} \equiv \mathrm{C} /$ arylamine $/ \mathrm{C} \equiv \mathrm{C} / \mathrm{Ru})$, and $[\mathbf{1 b}]^{+}(\mathrm{Fe} / \mathrm{C} \equiv \mathrm{C} / \mathrm{arylamine} / \mathrm{C} \equiv \mathrm{C} / \mathrm{Fe})$. Contour values: $\pm 0.04\left(\mathrm{e} / \mathrm{bohr}^{3}\right)^{1 / 2}$. BLYP35/6-31G* $(\mathrm{Ru} / \mathrm{Fe}: \mathrm{Lanl} 2 \mathrm{DZ}) / \mathrm{CPCM} / \mathrm{CH}_{2} \mathrm{Cl}_{2}$.

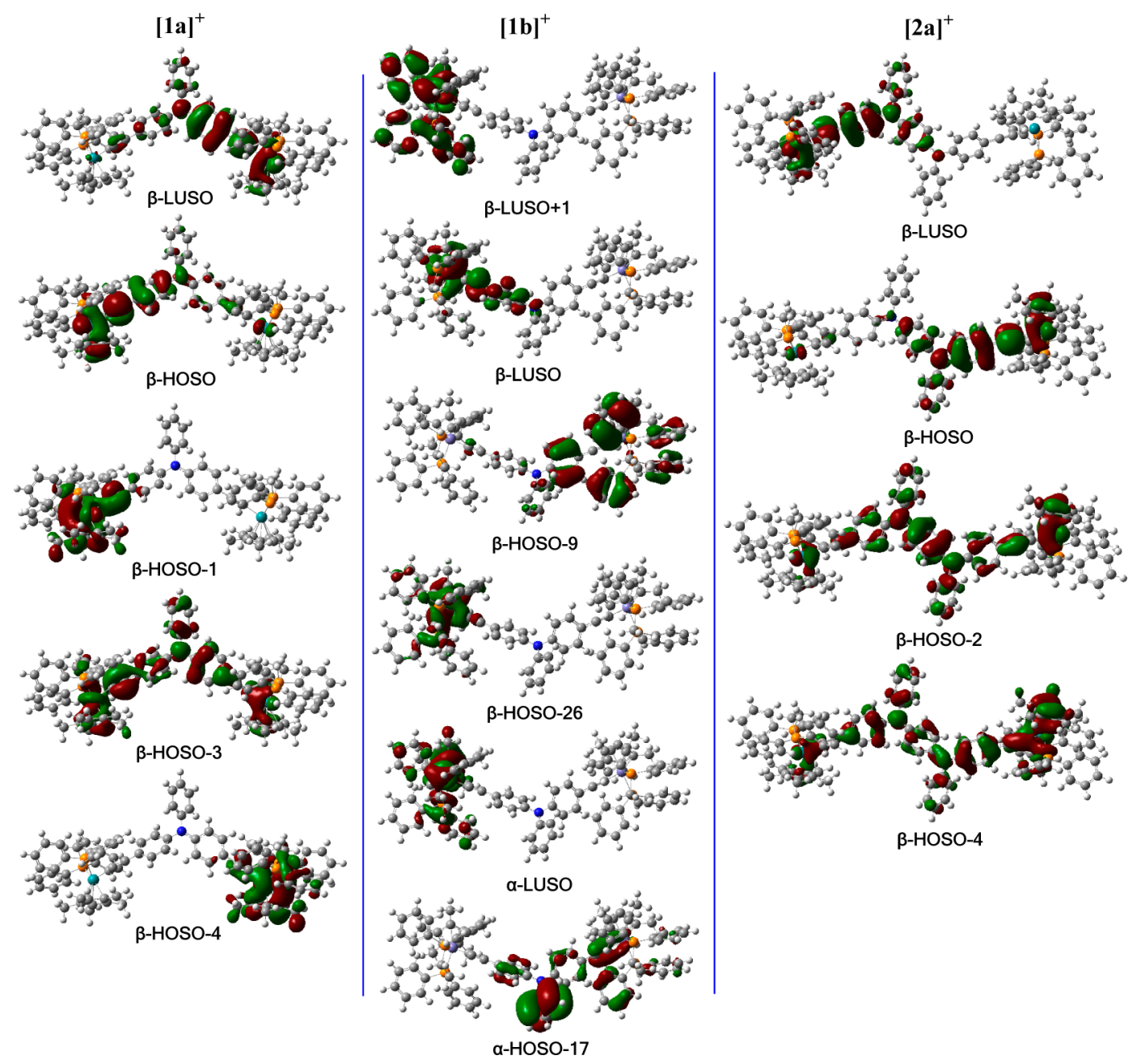

Figure 7. Spin orbitals involved in the major electronic excitations in $[\mathbf{1 a}]^{+}($left $),[\mathbf{1 b}]^{+}\left(\right.$middle), and $[\mathbf{2 a}]^{+}($right $)$presented in Table $5(\mathrm{D}=$ doublet). BLYP35/6-31G* (Ru/Fe: Lanl2DZ) /CPCM/ $\mathrm{CH}_{2} \mathrm{Cl}_{2}$.

308 that the oxidized $\mathrm{Ru}-\mathrm{C} \equiv \mathrm{C}$ units in precursor $[\mathbf{1 a}]^{2+}$ 309 somewhat affects the absorption of the cationic bridge-core in $310[\mathbf{1 a}]^{3+}$, causing its different position and band shape compared 311 to $[\mathbf{1 d}]^{+}$. Thus, the third anodic step of $1 \mathrm{a}$ is mainly localized on the TPA core, in agreement with the foregoing voltammetric 312 and IR spectro-electrochemical results.

313

The stepwise oxidation of $\mathbf{1 b}$ to $[\mathbf{1 b}]^{2+}$ was accompanied by 314 the instantaneous growth of an intense symmetric absorption 315 
Table 5. Major Electronic Excitations in $[1 \mathrm{la}]^{+},[1 \mathrm{~b}]^{+}$, and $[2 \mathrm{a}]^{+}$Determined by the TD-DFT Method ${ }^{a}$

\begin{tabular}{|c|c|c|c|c|c|c|}
\hline complex & $\begin{array}{l}\text { excited } \\
\text { state }\end{array}$ & $\begin{array}{c}\lambda(\mathrm{nm}) \\
{\left[\tilde{v}\left(\mathrm{~cm}^{-1}\right)\right]}\end{array}$ & $\begin{array}{l}\text { osc strength } \\
(f)\end{array}$ & major contributions & assignment & $\tilde{v}\left(\mathrm{~cm}^{-1}\right)$ (experiment) \\
\hline \multirow[t]{4}{*}[\mathbf{1}\mathbf{a}]{$^{+}$} & \multirow[t]{2}{*}{$\mathrm{D}_{2}$} & \multirow[t]{2}{*}{$1306[7655]$} & \multirow[t]{2}{*}{0.43} & $\beta$-HOSO $\rightarrow \beta$-LUSO $(77 \%)$ & $\begin{array}{l}\mathrm{Ru}(1)-\mathrm{C} \equiv \mathrm{C}(\mathrm{Ph}) \rightarrow \mathrm{Ru}(2)-\mathrm{C} \equiv \mathrm{C}(\mathrm{Ph})^{+} \mathrm{IVCT} / \\
\quad \mathrm{LLET}\end{array}$ & \multirow[t]{2}{*}{7900} \\
\hline & & & & $\begin{array}{l}\beta \text {-HOSO-4 } \rightarrow \beta \text {-LUSO } \\
(23 \%)\end{array}$ & $\mathrm{Ru}(2)(\mathrm{dppe}) \mathrm{Cp}^{*} \rightarrow \mathrm{Ru}(2)-\mathrm{C} \equiv \mathrm{C}(\mathrm{Ph})^{+} \mathrm{CT}$ & \\
\hline & \multirow[t]{2}{*}{$\mathrm{D}_{4}$} & \multirow[t]{2}{*}{807 [12 390] } & \multirow[t]{2}{*}{0.10} & $\begin{array}{l}\beta \text {-HOSO- } 1 \rightarrow \beta \text {-LUSO } \\
(60 \%)\end{array}$ & $\mathrm{Cp}^{*} \mathrm{Ru}(1)-\mathrm{C} \equiv \mathrm{C} \rightarrow \mathrm{Ru}(2)-\mathrm{C} \equiv \mathrm{C}(\mathrm{Ph})^{+} \mathrm{CT}$ & \multirow[t]{2}{*}{10400} \\
\hline & & & & $\begin{array}{l}\beta \text {-HOSO-3 } \\
(33 \%)\end{array}$ & $\mathrm{Ru}(1)-\mathrm{C} \equiv \mathrm{C}-\mathrm{TPA} \rightarrow \mathrm{Ru}(2)-\mathrm{C} \equiv \mathrm{C}(\mathrm{Ph})^{+} \mathrm{CT}$ & \\
\hline \multirow[t]{4}{*}[\mathbf{1b}]{$^{+}$} & \multirow[t]{2}{*}{$\mathrm{D}_{4}$} & \multirow[t]{2}{*}{$1051[9515]$} & \multirow[t]{2}{*}{0.13} & $\begin{array}{l}\beta \text {-HOSO-26 } \rightarrow \beta \text {-LUSO } \\
(49 \%)\end{array}$ & $\mathrm{Cp}^{*}(\text { at } \mathrm{Fe}(2))^{+} \rightarrow \mathrm{Fe}(2)-\mathrm{C} \equiv \mathrm{C}(\mathrm{Ph})^{+}$ILET & \multirow[t]{2}{*}{$\begin{array}{l}<10000 \text { (unresolved } \\
\tilde{v}_{\max } \text { ) }\end{array}$} \\
\hline & & & & $\begin{array}{l}\beta \text {-HOSO-9 } \rightarrow \beta \text {-LUSO } \\
(38 \%)\end{array}$ & $\mathrm{Cp} *($ dppe $) \mathrm{C} \equiv \mathrm{C} \rightarrow \mathrm{Fe}(2) \mathrm{C} \equiv \mathrm{C}(\mathrm{Ph})^{+} \mathrm{CT}$ & \\
\hline & \multirow[t]{2}{*}{$\mathrm{D}_{10}$} & \multirow[t]{2}{*}{$568[17605]$} & \multirow[t]{2}{*}{0.029} & $\begin{array}{l}\beta \text {-HOSO-26 } \rightarrow \beta \text {-LUSO }+1 \\
\quad(32 \%)\end{array}$ & $\mathrm{Cp}^{*}(\text { at } \mathrm{Fe}(2))^{+} \rightarrow$ dppe $(\text { at } \mathrm{Fe}(2))^{+}$ & \multirow[t]{2}{*}{ not observed } \\
\hline & & & & $\begin{array}{l}\alpha \text {-HOSO-17 } \rightarrow \alpha \text {-LUSO } \\
(32 \%)\end{array}$ & $\mathrm{TPA}(\mathrm{C} \equiv \mathrm{C}) \rightarrow \mathrm{FeCp}^{*}(\mathrm{dppe})^{+}$ & \\
\hline \multirow[t]{4}{*}[\mathbf{2a}]{$^{+}$} & \multirow[t]{2}{*}{$\mathrm{D}_{3}$} & \multirow[t]{2}{*}{$1091[9165]$} & \multirow[t]{2}{*}{0.14} & $\begin{array}{l}\beta \text {-HOSO-2 } \rightarrow \beta \text {-LUSO } \\
(75 \%)\end{array}$ & $\begin{array}{l}\mathrm{Ru}(1)-\mathrm{C} \equiv \mathrm{C}-\mathrm{TPPD} \rightarrow \mathrm{Ru}(2)-\mathrm{C} \equiv \mathrm{C}(\mathrm{Ph})^{+} \\
\mathrm{ILET} / \mathrm{IVCT}\end{array}$ & \multirow[t]{2}{*}{8400} \\
\hline & & & & $\beta$-HOSO $\rightarrow \beta$-LUSO $(25 \%)$ & $\begin{array}{l}\mathrm{Ru}(1)-\mathrm{C} \equiv \mathrm{C}(\mathrm{Ph}) \rightarrow \mathrm{Ru}(2)-\mathrm{C} \equiv \mathrm{C}(\mathrm{Ph})^{+} \mathrm{IVCT} / \\
\mathrm{ILET}\end{array}$ & \\
\hline & \multirow[t]{2}{*}{$\mathrm{D}_{6}$} & \multirow[t]{2}{*}{$661[15130]$} & \multirow[t]{2}{*}{0.061} & $\begin{array}{l}\beta \text {-HOSO- } 4 \rightarrow \beta \text {-LUSO } \\
(65 \%)\end{array}$ & $\begin{array}{l}\mathrm{Ru}(1)-\mathrm{C} \equiv \mathrm{C}-\mathrm{TPPD} \rightarrow \mathrm{Ru}(2)-\mathrm{C} \equiv \mathrm{C}(\mathrm{Ph})^{+} \\
\mathrm{ILET} / \mathrm{IVCT}\end{array}$ & \multirow[t]{2}{*}{10300} \\
\hline & & & & $\begin{array}{l}\beta \text {-HOSO- } 2 \rightarrow \beta \text {-LUSO } \\
(15 \%)\end{array}$ & $\begin{array}{l}\mathrm{Ru}(1)-\mathrm{C} \equiv \mathrm{C}-\mathrm{TPPD} \rightarrow \mathrm{Ru}(2)-\mathrm{C} \equiv \mathrm{C}(\mathrm{Ph})^{+} \\
\text {ILET/IVCT }\end{array}$ & \\
\hline
\end{tabular}

316 band at $1.12 \times 10^{4} \mathrm{~cm}^{-1}$ (Figure 5), reflecting the redox 317 disproportionation of $[\mathbf{1 b}]^{+}$to the stable dication and parent $318 \mathbf{~} \mathbf{b}$, in agreement with the IR monitoring of the initial anodic 319 process (see above). The low-energy absorption of $[\mathbf{1 b}]^{2+}$ is 320 reminiscent of ligand-to-metal charge transfer transitions in 321 formally $\mathrm{Fe}(\mathrm{III})$ complexes $\left[\{\mathrm{Fe}(\mathrm{dppe}) \mathrm{Cp} *(\mathrm{C} \equiv \mathrm{C}-)\}_{n}(\mathrm{Ph})\right]^{n+}$ $322(n=1,2){ }^{30}$ The striking difference in the NIR electronic 323 absorption between $[\mathbf{1 b}]^{2+}$ and $[\mathbf{1} \mathbf{a}]^{2+}$, combined with the 324 poorly separated anodic waves in the former case, does not 325 support participation of the TPA bridge core in the initial 326 oxidation of $\mathbf{1 b}$. The latter process occurs probably during the 327 subsequent well-separated oxidation of $[\mathbf{1 b}]^{2+}$ to $[\mathbf{1} \mathbf{b}]^{3+}$ (Figure $328 \mathrm{~S} 8$ ), as indicated by the comparison with the similar electronic 329 absorption of reference $[\mathbf{1 d}]^{+}$(Figure S10) as well as the 330 invariant $\operatorname{IR} \nu(\mathrm{C} \equiv \mathrm{C})$ band during this anodic step (Figure 3, 331 right). The product of the initial one-electron oxidation step, $332[\mathbf{1 b}]^{+}$, is hardly observable during the UV-vis-NIR spectro333 electrochemical monitoring of the anodic conversion of $\mathbf{1 b}$ to $334[\mathbf{1 b}]^{2+}$ due to the aforementioned redox disproportionation 335 process. However, the weak NIR absorption below $1.1 \times 10^{4}$ $336 \mathrm{~cm}^{-1}$, attributed to unstable $[\mathbf{1 b}]^{+}$, is clearly seen in the course 337 of the chemical oxidation of $\mathbf{1 b}$ with 1 equiv of $\mathrm{FcPF}_{6}$ 338 (Supporting Information, Figure S6); its assignment, different 339 from an intervalence charge transfer (IVCT), is presented in 340 the following theoretical (time-dependent (TD) DFT) section. 341 The observed characteristic UV-vis-NIR spectral changes 342 resulting from the stepwise oxidation of TMS-terminated 343 reference compound $\mathbf{2 d}$ to the corresponding mono- and 344 dication (Supporting Information, Figure S11) are fully 345 consistent with the spectral evolution reported in the 346 literature $^{31}$ for bare TPPD lacking the ethynyl linkers. By 347 contrast, the partly resolved first and second anodic steps of 348 diruthenium diethynyl-TPPD complex 2 a gave rise to UV349 vis-NIR absorption changes (Supporting Information, Figure 350 S12) strongly resembling the generation of monocationic 351 diethynyl-TPA-bridged species $[\mathbf{1 a}]^{+}$, which also matched their similar IR $\nu(\mathrm{C} \equiv \mathrm{C})$ shifts described in the preceding text. 352 Stable $[\mathbf{2 a}]^{3+}$ is then characterized by a new UV-vis-NIR 353 absorption (Figure S12, bottom) assigned to the oxidized 354 radical-cationic TPPD core in $[\mathbf{2 a}]^{3+}$, which is evident from the 355 comparison with the low-lying electronic absorption of 356 reference $[\mathbf{2 d}]^{+}$(Figure S11) as well as the negligible change 357 in the $\nu\left(\mathrm{C} \equiv \mathrm{C}\right.$ ) wavenumber on oxidation of $[\mathbf{2 a}]^{2+}$ (Figure 358 S3).

Theoretical Calculations. DFT calculations, using the 360 BLYP35 functional, were performed to gain insight into the 361 electronic structures of the one-electron-oxidized open-shell 362 species $[\mathbf{1 a}]^{+},[\mathbf{1 b}]^{+}$, and $[\mathbf{2 a}]^{+}$, although the latter two cations 363 were not generated in the pure forms during the spectro- 364 electrochemical experiments due to valence disproportionation 365 equilibria resulting in their mixture with the corresponding 366 dications. This applies especially for $[\mathbf{1 b}]^{+}$detected only in a 367 very small amount (Supporting Information, Figure S6). The 368 basis set employed here is 6-31G* (Lanl2DZ for $\mathrm{Ru}$ and $\mathrm{Fe} 369$ atoms). The BLYP35 method reported by Kaupp and co- 370 workers is appropriate for triarylamine and organometallic 371 complexes similar to our systems. ${ }^{25,32}$ All the calculations were 372 performed on nontruncated complexes $[\mathbf{1} \mathbf{a}]^{+},[\mathbf{1} \mathbf{b}]^{+}$, and $[\mathbf{2} \mathbf{a}]^{+} 373$ to warrant their accuracy, regardless of the relatively heavy 374 computing burden. To account also for solvent effects, the 375 conductor polarizable continuum model (CPCM) in $\mathrm{CH}_{2} \mathrm{Cl}_{2} 376$ was employed for the ground-state structural optimization and 377 analyses as well as in TD-DFT calculations of the electronic $378 \mathrm{f} 6$ excitation energies. The pertinent data are presented in Figures $379 \mathrm{f} 6$ 6 and 7, Supporting Information, Figures S13 and S14, and $380 \mathrm{f6f7}$ Table 5. $381 \mathrm{t} 5$

The DFT results indicate similar geometric changes taking 382 place upon the one-electron oxidation of diruthenium 383 complexes 1a and 2a (see Supporting Information, Figure 384 S14). The anodic electron transfer results in dominant 385 elongation of one of the $\mathrm{C} \equiv \mathrm{C}$ bonds and shorter adjacent 386 (ethynyl)C-Ru, (ethynyl)C-C(phenylene), and $\mathrm{N}-\mathrm{C}-387$ 
388 (phenylene) bonds. The differences between the neutral and 389 monocationic states are greater for 1a. The diethynyl-TPA 390 bridge is more involved in the initial oxidation of 1a than the 391 diethynyl-TPPD bridge in $\mathbf{2 a}$, in agreement with the larger 392 separation of the first two anodic waves for 1a (Figure 2 and 393 Table 2) reflecting a stronger electronic interaction between 394 the $\mathrm{Ru}$ centers mediated by the diethynyl-TPA bridge. In 395 contrast, no significant changes in the bonding characteristics of 396 the diethynyl-TPA bridge accompanied the model oxidation of $397 \mathbf{~} \mathbf{b}$ that is localized exclusively on the metallic termini. The 398 iron-Cp* centers oxidize independently, and the mixed399 valence species, $[\mathbf{1 b}]^{+}$, is unstable with respect to redox 400 disproportionation and conversion to $[\mathbf{1 b}]^{2+}$, as was revealed by 401 the UV-vis-NIR spectroscopic monitoring of the anodic path. 402 However, the experimental IR spectro-electrochemical results 403 (Table 3) illustrate that the ethynyl linkers are still involved in 404 the initial oxidation of $\mathbf{1 b}$, although much less than encountered 405 in both diruthenium complexes, 1a and 2 a.

406 The important complementary results obtained with DFT 407 for the spin density distribution in $[\mathbf{1} \mathbf{a}]^{+},[\mathbf{1 b}]^{+}$, and $[\mathbf{2} \mathbf{a}]^{+}$are 408 shown in Figure 6. Apparently, the spin localization in $[\mathbf{1 a}]^{+}$ 409 and, increasingly, in $[\mathbf{2 a}]^{+}$and $[\mathbf{1 b}]^{+}$is asymmetric, residing 410 largely on the ruthenium-ethynyl(-phenylene) and iron-Cp* 411 redox centers, respectively, in one-half of the molecule, which is 412 fully consistent with the symmetry-broken triple bond 413 stretching induced by the initial oxidation of $\mathbf{1 a}, \mathbf{2 a}$, and $\mathbf{1 b}$ 414 (vide supra). Not surprisingly, the asymmetric spin of $[\mathbf{1 a}]^{+}$ 415 exhibits a delocalized distribution in contrast to the strongly 416 localized oxidation of $\mathbf{1 b}$, again affirming the effect of the 417 different metal centers on the anodic behavior.

418 Also worth mentioning is the difference in the spin 419 distribution calculated for radical cations $[\mathbf{1} \mathbf{a}]^{+}$and $[\mathbf{2 a}]^{+}$ 420 featuring the different bridge cores (Figure 6). In contrast to 421 the delocalized asymmetric spin distribution in $[\mathbf{1 a}]^{+}$, the spin 422 density in $[2 \mathbf{a}]^{+}$is localized more on one of the $\mathrm{Ru}$ centers and 423 less on the bridge core, with no apparent involvement of the 424 remote ruthenium-ethynyl unit, thereby matching well the 425 weak electronic coupling between the ruthenium centers across 426 the elongated TPPD bridge core in $[\mathbf{2 a}]^{+}$illustrated by the 427 experimental results.

428 TD-DFT calculations were performed to reproduce the low429 energy absorption features in the experimental UV-vis-NIR 430 spectra of the monocationic diethynyl monoamine and diamine 431 complexes and to facilitate their assignment in support of the 432 spin-localized bonding situation (Figure 6). The relevant 433 electronic transitions are presented in Table 5 and depicted 434 in Figure 7. According to the TD-DFT results, the NIR band of $435[\mathbf{1 a}]^{+}$at $7800 \mathrm{~cm}^{-1}\left(\nu_{2}\right.$ in Figure S9 and Table S2, Supporting 436 Information) has been well-duplicated and can mainly be 437 attributed to the $\beta$-HOSO $\rightarrow \beta$-LUSO transition $(\mathrm{HOSO}=$ 438 highest occupied system orbital; LUSO = lowest unoccupied 439 system orbital). The $\beta$-HOSO is primarily localized on the 440 nonoxidized $\mathrm{Ru}-\mathrm{C} \equiv \mathrm{C}$ unit $(70 \%)$, imparting the correspond441 ing transition an appreciable IVCT character. The electronic 442 coupling parameter, $H_{\mathrm{ab}}=685 \mathrm{~cm}^{-1}$, was determined from the 443 Hush formula, $H_{\mathrm{ab}}=\left(2.06 \times 10^{-2} / R_{\mathrm{ab}}\right)\left(\varepsilon_{\max } \nu_{\max } \Delta \nu\right)^{1 / 2}$ (ref 44433 ), in which $R_{\mathrm{ab}}$ is the distance between the ruthenium centers 445 in the X-ray crystal structure (Figure 1 ). Hence, $[\mathbf{1 a}]^{+}$can be 446 classified as a moderately coupled Robin-Day Class II mixed447 valence compound. The higher-lying electronic transition 448 computed at $12390 \mathrm{~cm}^{-1}$ is most likely responsible for the 449 absorption band of $[1 \mathrm{a}]^{+}$at $10200 \mathrm{~cm}^{-1}\left(\nu_{1}\right.$ in Figure S9 and 450 Table S2, Supporting Information). It involves both $\beta$-HOSO-1 and $\beta$-HOSO- 3 so that the associated charge transfer to the 451 oxidized $\mathrm{Ru}(2)-\mathrm{C} \equiv \mathrm{C}(\mathrm{Ph})^{+}$site of $[\mathbf{1 a}]^{+}$also involves the 452 $\mathrm{Cp}^{*}(\mathrm{Ru})$ and TPA donor sites.

453

Complex $[\mathbf{1 b}]^{+}$exhibits an NIR excitation at $9515 \mathrm{~cm}^{-1} 454$ belonging to $\beta$-HOSO- $26 \rightarrow \beta$-LUSO and $\beta$-HOSO- $\rightarrow \rightarrow \beta-455$ LUSO transitions. The dominant former component is 456 localized at the oxidized metallic site, having a partial inter- 457 configurational (IC) character typically observed for similar 458 predominantly $\mathrm{Fe}(\mathrm{III})$ systems. $^{24,34}$ The acceptor ethynyl(- 459 phenylene) and donor C $\mathrm{p}^{*}$ frameworks are also involved. The 460 second component represents a charge transfer from a ligand- 461 based $\pi$-orbital delocalized in the nonoxidized half of $[\mathbf{1 b}]^{+}$. A 462 convincing experimental evidence for this low-energy electronic 463 absorption in valence-localized $[\mathbf{1 b}]^{+}$with weakly interacting $\mathrm{Fe} 464$ centers is shown in Figure S6 (Supporting Information). The 465 calculated visible electronic absorption of $[\mathbf{1 b}]^{+}$could not be 466 verified experimentally (Figure 5 and Supporting Information, 467 Figure S6) due to the redox disproportionation of the cation 468 and the tailing absorption of $[\mathbf{1} \mathbf{b}]^{2+}$ in that region. 469

The asymmetric NIR absorptions of $[2 \mathbf{a}]^{+}$at ca. 8400 and 470 $10300 \mathrm{~cm}^{-1}$ have been reproduced less accurately than in the 471 case of $\left[\mathbf{1 a}^{+}\right]$, probably due to the exaggerated planar 472 conformation of TPPD seen in the computed model. The 473 calculated excitations encompass the dominant $\beta$-HOSO- $2 \rightarrow \beta-474$ LUSO and $\beta$-HOSO- $4 \rightarrow \beta$-LUSO transitions, respectively. Both 475 $\beta$-HOSO-2 and $\beta$-HOSO- 4 are delocalized over the planar 476 TPPD core and the nonoxidized $\mathrm{Ru}-\mathrm{C} \equiv \mathrm{C}$ unit. Similar to 477 $[\mathbf{1 a}]^{+}$, the $\beta$-LUSO resides on the oxidized $\mathrm{Ru}(2)-\mathrm{C} \equiv \mathrm{C}(\mathrm{Ph})^{+} 478$ site. The IVCT character of the lowest NIR absorption of $[\mathbf{2 a}]^{+} 479$ becomes enhanced by the $25 \%$ admixture of the $\beta$-HOSO $\rightarrow \beta-480$ LUSO component.

\section{CONCLUSIONS}

482

The electrochemical results reveal that homo-bimetallic 483 complexes 1a, $\mathbf{1 b}$, and $\mathbf{2 a}$ undergo multistep oxidation 484 processes. The monocationic state of $1 \mathrm{a}$ is stable, with a large 485 $K_{\mathrm{c}}$ value compared to $[\mathbf{1 b}]^{+}$that tends to disproportionate to 486 the corresponding dication. Likewise, instability was also 487 expected for $[\mathbf{2 a}]^{+}$with the extended diamine bridge core, 488 based on the similar poorly resolved first two anodic responses 489 of $\mathbf{1 b}$ and $\mathbf{2 a}$. However, [2a $]^{+}$could still readily be detected 490 with in situ UV-vis-NIR spectroscopy, bearing a strong 491 resemblance to $[\mathbf{1 a}]^{+}$. Combined results of IR and UV/vis/NIR 492 spectro-electrochemistry and DFT/TD-DFT calculations of 493 nontruncated models have demonstrated that (i) there exists an 494 appreciable electronic interaction between the two ruthenium 495 centers in $[\mathbf{1 a}]^{+}$; (ii) the first two oxidation steps of $\mathbf{1 b}$ are 496 largely Fe-localized; (iii) the spectroscopic characteristics of 497 $[2 \mathrm{a}]^{+}$indicate much weaker electronic interaction between two 498 ruthenium centers through the extended TPPD bridge core; 499 (iv) the subsequent oxidation of the dications of $\mathbf{1 a}, \mathbf{1} \mathbf{b}$, and $\mathbf{2 a} 500$ is localized on the arylamine bridge core (as revealed by IR 501 spectro-electrochemistry and the comparison with the anodic 502 behavior of the corresponding TMS-terminated derivatives). 503 The elongated TPPD linker, with more twisted conformation 504 and restricted $\pi$-conjugation, indeed, exhibits electronic 505 insulation properties to some extent. Notably, a planar 506 conformation of TTPD in $[\mathbf{2 a}]^{+}$and its stronger involvement 507 in the initial oxidation than inferred from the experimental data 508 have emerged from DFT calculations of the model complex. 509 The alternative linear $\pi$-conjugated oligoarylamine structures 510 will be the subject of our following report on long-range 511 electron transfer systems. Furthermore, this work may be 512 
513 expedient for designing and investigating more diversified 514 systems with multiple redox states.

\section{EXPERIMENTAL SECTION}

516 General Materials. All manipulations were performed under a dry 517 argon gas atmosphere by using standard Schlenk techniques, unless 518 stated otherwise. Solvents were predried and distilled under argon 519 prior to use, except those used directly for spectroscopic measure520 ments, which were of spectroscopic grade. The starting materials 4521 bromo- $N$-(4-bromophenyl)- $N$-phenylaniline (1c), ${ }^{35} \mathrm{~N}^{1}, N^{4}$-bis(4-bro522 mophenyl)- $N^{1}, N^{4}$-diphenylbenzene-1,4-diamine (2c) ${ }^{36}[\mathrm{RuCl}(\mathrm{dppe})$ $\left.523 \mathrm{Cp}^{*}\right],{ }^{37}$ and $\left[\mathrm{FeCl}(\mathrm{dppe}) \mathrm{Cp}^{*}\right]^{38}$ were prepared by the procedures 524 described in the literature. Target complexes $\mathbf{1 a}-\mathbf{1 b}$ and $\mathbf{2 a}$ were 525 prepared along the synthetic route presented in Scheme 1. Other 526 reagents were purchased and used as received.

527 Syntheses. Intermediate $1 d$. To a stirred solution of precursor $1 \mathrm{c}$ $528(806 \mathrm{mg}, 2 \mathrm{mmol}), \mathrm{CuI}(38 \mathrm{mg}, 0.2 \mathrm{mmol})$, and $\left[\mathrm{Pd}\left(\mathrm{PPh}_{3}\right)_{4}\right](231$ $529 \mathrm{mg}, 0.2 \mathrm{mmol}$ ) in triethylamine $(20 \mathrm{~mL})$ and tetrahydrofuran (THF; $53030 \mathrm{~mL}$ ) under an argon atmosphere trimethylsilylacetylene $(588 \mathrm{mg}, 6$ $531 \mathrm{mmol}$ ) was added, and the mixture was held at $60^{\circ} \mathrm{C}$ for $24 \mathrm{~h}$. After it 532 cooled, the solution was filtered through a bed of diatomaceous earth. 533 The filtrate was evaporated under reduced pressure and purified by 534 silica gel column chromatography (petroleum ether) to give a light 535 yellow solid (753 mg, yield $86 \%$ ). ${ }^{1} \mathrm{H}$ NMR $\left(400 \mathrm{MHz}, \mathrm{CDCl}_{3}\right): \delta$ $5360.25\left(\mathrm{~s}, 18 \mathrm{H}, \mathrm{SiMe}_{3}\right), 6.96\left(\mathrm{~d}, \mathrm{~J}_{\mathrm{HH}}=8 \mathrm{~Hz}, 4 \mathrm{H}, \mathrm{Ar}-\mathrm{H}\right), 7.06-7.11(\mathrm{~m}$, $5374 \mathrm{H}, \mathrm{Ar}-\mathrm{H}), 7.32-7.34\left(\mathrm{~d}, J_{\mathrm{HH}}=8 \mathrm{~Hz}, 5 \mathrm{H}, \mathrm{Ar}-\mathrm{H}\right) .{ }^{13} \mathrm{C}$ NMR $(100$ $\left.538 \mathrm{MHz}, \mathrm{CDCl}_{3}\right): \delta 0.03\left(\mathrm{SiMe}_{3}\right), 93.5,105.1(\mathrm{C} \equiv \mathrm{C}), 116.9,123.1$, $539124.1,124.9,125.3,129.3,129.5,133.0,146.5,147.3(\mathrm{Ar})$, as reported 540 in ref 39.

541 Intermediate $\mathbf{2 d}$. Compound $\mathbf{2} \mathbf{d}$ was prepared from precursor $\mathbf{2 c}$ 542 by a method analogous to that employed for $1 \mathbf{d}$ and purified on a silica 543 gel column (petroleum ether/dichloromethane $=10: 1, \mathrm{v} / \mathrm{v}$ ) to obtain 544 a light yellow solid (980 mg, yield $81 \%) .{ }^{1} \mathrm{H}$ NMR (400 $\mathrm{MHz}$, $\left.545 \mathrm{CDCl}_{3}\right): \delta 0.24\left(\mathrm{~s}, 18 \mathrm{H}, \mathrm{SiMe}_{3}\right), 6.98-7.10(\mathrm{~m}, 14 \mathrm{H}, \mathrm{Ar}-\mathrm{H}), 7.28-$ $5467.31(\mathrm{~m}, 8 \mathrm{H}, \mathrm{Ar}-\mathrm{H}) .{ }^{13} \mathrm{C} \mathrm{NMR}\left(100 \mathrm{MHz}, \mathrm{CDCl}_{3}\right): \delta 0.28\left(\mathrm{SiMe}_{3}\right)$, 547 93.0, 105.3 (C三C), 115.8, 121.8, 123.4, 124.7, 125.6, 129.3, 132.8, 548 142.4, 146.8, 147.7 (Ar). EI-MS: $m / z=604.55[\mathrm{M}]^{+}$. Anal. Calcd for $549 \mathrm{C}_{40} \mathrm{H}_{40} \mathrm{~N}_{2} \mathrm{Si}_{2}: \mathrm{C}, 79.42 ; \mathrm{H}, 6.66 ; \mathrm{N}, 4.63$. Found: $\mathrm{C}, 79.63 ; \mathrm{H}, 6.58 ; \mathrm{N}$, $5504.67 \%$.

551 Homo-Bimetallic Complexes $\mathbf{1 a}, \mathbf{1 b}$, and $2 \boldsymbol{a}$. Target compounds $552 \mathbf{1 a}, \mathbf{1} \mathbf{b}$, and $\mathbf{2 a}$ were prepared along the synthetic route presented in 553 Scheme 1 .

$\left.554 \quad\left[\{R u(d p p e) C p *(C \equiv C)\}_{2}\right\}(\mu-T P A)\right]$ (1a). A solution of [RuCl(dppe)$\left.555 \mathrm{Cp}^{*}\right](321 \mathrm{mg}, 0.50 \mathrm{mmol})$, $1 \mathrm{~d}(100 \mathrm{mg}, 0.23 \mathrm{mmol})$, and $\mathrm{KF}(160$ $556 \mathrm{mg}, 2.76 \mathrm{mmol})$ in $\mathrm{CH}_{3} \mathrm{OH}(20 \mathrm{~mL})$ and $\mathrm{THF}(5 \mathrm{~mL})$ was heated to 557 reflux under nitrogen atmosphere for $24 \mathrm{~h}$. The crude product was 558 collected by filtration and washed with hexane. The solid was dissolved 559 in dichloromethane and precipitated by slow diffusion of hexane. The 560 solid was filtered off and dried to give $1 \mathrm{a}$ as a yellow powder $(312 \mathrm{mg}$, 561 yield $87 \%) .{ }^{1} \mathrm{H}$ NMR $\left(400 \mathrm{MHz}, \mathrm{CDCl}_{3}\right): \delta 1.56\left(\mathrm{~s}, 30 \mathrm{H}, \mathrm{CH}_{3}\right.$ of $\left.562 \mathrm{C}_{5} \mathrm{Me}_{5}\right), 2.03-2.08\left(\mathrm{~m}, 4 \mathrm{H}, \mathrm{CH}_{2}\right.$ of dppe), 2.66-2.71 (m, 4H, $\mathrm{CH}_{2}$ of 563 dppe), 6.65-6.76 (m, 8H, Ar-H), 6.86-6.87 (m, 1H, Ar-H), 6.99 (d, $5642 \mathrm{H}, J=8 \mathrm{~Hz} \mathrm{Ar}-\mathrm{H}), 7.13-7.35(\mathrm{~m}, 34 \mathrm{H}, \mathrm{Ar}-\mathrm{H}), 7.79$ (br, 8H, Ar$565 \mathrm{H}) .{ }^{13} \mathrm{C}$ NMR $\left(100 \mathrm{MHz}, \mathrm{CDCl}_{3}\right): \delta 10.1\left(\mathrm{CH}_{3}\right.$ of $\left.\mathrm{C}_{5} \mathrm{Me}_{5}\right), 29.2-31.6$ $566\left(\mathrm{~m}, \mathrm{CH}_{2}\right.$ of dppe), $92.4\left(\mathrm{CH}_{3}\right.$ of $\left.\mathrm{C}_{5} \mathrm{Me}_{5}\right), 109.1(\mathrm{Ru}-\mathrm{C} \equiv \mathrm{C}), 122.4$ $567(\mathrm{Ru}-\mathrm{C} \equiv \mathrm{C}), 123.9-148.3(\mathrm{~m}, \mathrm{Ar}) .{ }^{31} \mathrm{P}$ NMR $\left(160 \mathrm{MHz}, \mathrm{CDCl}_{3}\right): \delta$ 56878.97 (s, dppe). IR $\left(\mathrm{KBr} / \mathrm{cm}^{-1}\right): \nu(\mathrm{C} \equiv \mathrm{C}) 2062(\mathrm{w})$. Anal. Calcd for $569 \mathrm{C}_{94} \mathrm{H}_{91} \mathrm{NP}_{4} \mathrm{Ru}_{2}$ : C, 72.34; H, 5.88; N, 0.90. Found: C, 72.56; H, 5.78; $570 \mathrm{~N}, 0.91 \%$.

571 $\left[\left\{\mathrm{Fe}(\mathrm{dppe}) \mathrm{C} \mathrm{p}^{*}(\mathrm{C} \equiv \mathrm{C})\right\}_{2}(\mu-T P A)\right](\mathbf{1 b})$. A solution of $\mathbf{1 d}(87 \mathrm{mg}, 0.20$ $572 \mathrm{mmol})$ and $\mathrm{K}_{2} \mathrm{CO}_{3}(61 \mathrm{mg}, 0.44 \mathrm{mmol})$ in $\mathrm{CH}_{3} \mathrm{OH}(30 \mathrm{~mL})$ and THF $573(10 \mathrm{~mL})$ was stirred for $10 \mathrm{~h}$ under nitrogen atmosphere at room 574 temperature. Then, $\left[\mathrm{FeCl}(\mathrm{dppe}) \mathrm{Cp}^{*}\right](275 \mathrm{mg}, 0.44 \mathrm{mmol})$ and $575 \mathrm{Na}\left[\mathrm{BPh}_{4}\right](151 \mathrm{mg}, 0.44 \mathrm{mmol})$ were added. After $16 \mathrm{~h}$ of stirring, $576 \mathrm{tBuOK}(52 \mathrm{mg}, 0.44 \mathrm{mmol})$ was introduced, and the mixture was 577 stirred for another $4 \mathrm{~h}$, after which the solvent was evaporated and the 578 residue was extracted with toluene $(4 \times 10 \mathrm{~mL})$. After the solvent 579 removal, washing with pentane $(3 \times 10 \mathrm{~mL})$, and vacuum drying, an 580 orange powder was obtained $(182 \mathrm{mg}, 0.12 \mathrm{mmol}$, yield $62 \%) .{ }^{1} \mathrm{H}$
NMR (400 MHz, $\left.\mathrm{CDCl}_{3}\right): \delta 1.41\left(\mathrm{~s}, 30 \mathrm{H}, \mathrm{CH}_{3}\right.$ of $\left.\mathrm{C}_{5} \mathrm{Me}_{5}\right), 1.96(\mathrm{br}, 581$ $4 \mathrm{H}, \mathrm{CH}_{2}$ of dppe), 2.64 (br, $4 \mathrm{H}, \mathrm{CH}_{2}$ of dppe), $6.69(\mathrm{br}, 4 \mathrm{H}, \mathrm{Ar}-\mathrm{H}), 582$ 6.81-6.83 (m, 5H, Ar-H), 7.02 (d, J=8 Hz, 2H, Ar-H), 7.24-7.34 583 $(\mathrm{m}, 34 \mathrm{H}, \mathrm{Ar}-\mathrm{H}), 7.91$ (br, 8H, Ar-H). ${ }^{13} \mathrm{C}$ NMR (100 MHz, 584 $\left.\mathrm{CDCl}_{3}\right): \delta 10.1\left(\mathrm{CH}_{3}\right.$ of $\left.\mathrm{C}_{5} \mathrm{Me}_{5}\right), 30.1-31.6\left(\mathrm{~m}, \mathrm{CH}_{2}\right.$ of dppe), 87.5585 $\left(\mathrm{CH}_{3}\right.$ of $\left.\mathrm{C}_{5} \mathrm{Me}_{5}\right), 121.0(\mathrm{Fe}-\mathrm{C} \equiv \mathrm{C}), 122.9-138.7(\mathrm{~m}, \mathrm{Ar}), 142.9586$ $(\mathrm{Fe}-\mathrm{C} \equiv \mathrm{C}) .{ }^{31} \mathrm{P}$ NMR $\left(160 \mathrm{MHz}, \mathrm{CDCl}_{3}\right): \delta 95.63$ (s, dppe). IR 587 $\left(\mathrm{KBr} / \mathrm{cm}^{-1}\right): \nu(\mathrm{C} \equiv \mathrm{C}) 2051(\mathrm{w})$. Anal. Calcd for $\mathrm{C}_{94} \mathrm{H}_{91} \mathrm{NP}_{4} \mathrm{Fe}_{2}: \mathrm{C}, 588$ 76.79; H, 6.24; N, 0.95. Found: C, 76.82; H, 6.22; N, 0.96\%.

[\{Ru(dppe) $\left.\left.C p^{*}(C \equiv C)\right\}_{2}(\mu-T P P D)\right]$ (2a). Complex 2a was prepared 590 by an analogous method as 1a, using the following amounts: 591 [RuCl(dppe)Cp*] (464 mg, $0.69 \mathrm{mmol}), 2 \mathrm{~d}$ (200 mg, $0.33 \mathrm{mmol}), 592$ and $\mathrm{KF}(273 \mathrm{mg}, 3.96 \mathrm{mmol})$ dissolved in $\mathrm{CH}_{3} \mathrm{OH}(20 \mathrm{~mL})$, THF (5 593 $\mathrm{mL})$. The product was obtained as a light green solid $(353 \mathrm{mg}, 62 \% 594$ yield). ${ }^{1} \mathrm{H}$ NMR ( $\left.400 \mathrm{MHz}, \mathrm{CDCl}_{3}\right): \delta 1.56\left(\mathrm{~s}, 30 \mathrm{H}, \mathrm{CH}_{3}\right.$ of $\left.\mathrm{C}_{5} \mathrm{Me}_{5}\right), 595$ 1.99-2.10 (m, $4 \mathrm{H}, \mathrm{CH}_{2}$ of dppe), 2.65-2.76 (m, $4 \mathrm{H}, \mathrm{CH}_{2}$ of dppe), 596 $6.70(\mathrm{~d}, 4 \mathrm{H}, J=8 \mathrm{~Hz}, \mathrm{Ar}-\mathrm{H}), 6.79(\mathrm{~d}, 4 \mathrm{H}, J=8 \mathrm{~Hz}, \mathrm{Ar}-\mathrm{H}), 6.87-597$ $6.92(\mathrm{~m}, 6 \mathrm{H}, \mathrm{Ar}-\mathrm{H}), 7.03(\mathrm{~d}, 4 \mathrm{H}, J=8 \mathrm{~Hz} \mathrm{Ar}-\mathrm{H}), 7.17-7.34$ (m, 598 $36 \mathrm{H}, \mathrm{Ar}-\mathrm{H}), 7.79$ (br, 8H, Ar-H). ${ }^{13} \mathrm{C}$ NMR $\left(100 \mathrm{MHz}, \mathrm{CDCl}_{3}\right): \delta 599$ $10.0\left(\mathrm{CH}_{3}\right.$ of $\left.\mathrm{C}_{5} \mathrm{Me}_{5}\right), 29.4-29.7\left(\mathrm{~m}, \mathrm{CH}_{2}\right.$ of dppe), $92.5\left(\mathrm{CH}_{3}\right.$ of 600 $\left.\mathrm{C}_{5} \mathrm{Me}_{5}\right), 122.6(\mathrm{Ru}-\mathrm{C} \equiv \mathrm{C}), 122.9(\mathrm{Ru}-\mathrm{C} \equiv \mathrm{C}), 127.1-133.8(\mathrm{~m}, 601$ $\mathrm{Ar}) .{ }^{31} \mathrm{P}$ NMR $\left(160 \mathrm{MHz}, \mathrm{CDCl}_{3}\right): \delta 70.86(\mathrm{~s}, \mathrm{dppe}) . \mathrm{IR}\left(\mathrm{KBr} / \mathrm{cm}^{-1}\right): 602$ $\nu(\mathrm{C} \equiv \mathrm{C}) 2067$ (s). Anal. Calcd for $\mathrm{C}_{106} \mathrm{H}_{100} \mathrm{~N}_{2} \mathrm{P}_{4} \mathrm{Ru}_{2}$ : C, 73.68; H, 603 5.83; N, 1.62. Found: C, 73.59; H, 5.80; N, $1.61 \%$.

604

X-ray Crystallography. Single crystals of complexes 1a and 2a 605 suitable for X-ray analysis were grown by layering a solution in 606 dichloromethane with hexane. Crystals with approximate dimensions 607 of $0.20 \times 0.20 \times 0.10 \mathrm{~mm}^{3}$ for $1 \mathrm{a}$ and $0.20 \times 0.20 \times 0.20 \mathrm{~mm}^{3}$ for $2 \mathrm{a} 608$ were mounted on glass fibers for diffraction experiments. Intensity data 609 were collected on a Nonius Kappa CCD diffractometer with Mo K $\alpha 610$ radiation $(0.71073 \AA)$ at room temperature. The crystal structures 611 were determined by a combination of direct methods (SHELXS-97) ${ }^{40} 612$ and Fourier difference techniques, and refined by full matrix least- 613 squares (SHELXL-97). ${ }^{41}$ All non-H atoms were refined anisotropi- 614 cally. The hydrogen atoms were placed in ideal positions and refined 615 as riding atoms. The partial solvent molecules were omitted. Further 616 crystal data and details of the data collection are summarized in Table 617 S1. Selected bond distances and angles are given in Table 1.

Physical Measurements. ${ }^{1} \mathrm{H},{ }^{13} \mathrm{C}$, and ${ }^{31} \mathrm{P}$ NMR spectra were 619 collected on a Varian Mercury Plus 400 spectrometer $(400 \mathrm{MHz}) .{ }^{1} \mathrm{H} 620$ and ${ }^{13} \mathrm{C}$ NMR chemical shifts are relative to $\mathrm{Si}\left(\mathrm{CH}_{3}\right)_{4}$, and ${ }^{31} \mathrm{P}$ NMR 621 chemical shifts are relative to $85 \% \mathrm{H}_{3} \mathrm{PO}_{4}$. Elemental analyses $(\mathrm{C}, \mathrm{H}, 622$ $\mathrm{N})$ were performed with a Vario ElIII Chnso instrument. The 623 electrochemical measurements were performed on a CHI $660 \mathrm{C} 624$ potentiostat. A three-electrode single-compartment cell was used for 625 the solution of complexes and supporting electrolyte in dry $\mathrm{CH}_{2} \mathrm{Cl}_{2} .626$ The solution was deaerated by argon bubbling on a frit for $\sim 10 \mathrm{~min} 627$ before the measurement. The analyte (complex, ligand) and 628 electrolyte $\left(n-\mathrm{Bu}_{4} \mathrm{NPF}_{6}\right)$ concentrations were typically $1 \times 10^{-3}$ and 629 $1 \times 10^{-1} \mathrm{~mol} \mathrm{dm}^{-3}$, respectively. A prepolished $500 \mu \mathrm{m}$ diameter 630 platinum disk working electrode, a platinum wire counter electrode, 631 and an $\mathrm{Ag}$ wire pseudoreference electrode were used. Ferrocene was 632 used as the internal potential reference. Spectro-electrochemical 633 experiments at room temperature were performed with an airtight 634 optically transparent thin-layer electrochemical (OTTLE) cell (optical 635 path length of ca. $200 \mu \mathrm{m}$ ) equipped with a Pt minigrid working 636 electrode and $\mathrm{CaF}_{2}$ windows. ${ }^{42}$ The cell was positioned in the sample 637 compartment of a Bruker Tensor Fourier transform IR spectrometer 638 $\left(1 \mathrm{~cm}^{-1}\right.$ spectral resolution, eight scans) or a Shimadzu UV-3600 UV- 639 vis-NIR spectro-photometer. The controlled-potential electrolyses 640 were performed with a $\mathrm{CHI} 660 \mathrm{C}$ potentiostat. The concentration of 641 analyte samples was ca. $2 \times 10^{-3} \mathrm{~mol} \mathrm{dm}^{-3}$. Dry $3 \times 10^{-1} \mathrm{M} \mathrm{n-642}$ $\mathrm{Bu}_{4} \mathrm{NPF}_{6}$ was used as the supporting electrolyte.

Computational Details. DFT calculations were performed with 644 the Gaussian 09 program, ${ }^{43}$ at the BLYP $35^{44} / 6-31 G^{*}$ level of theory. 645 The basis set employed was 6-31G* (Lanl2DZ for Ru and Fe atoms). 646 Geometry optimization was performed without any symmetry 647 constraints. Electronic transitions were calculated by the TD-DFT 648 method. The molecular orbital contributions were generated using the 649 Multiwfn package and plotted using GaussView 5.0. The solvation 650 
651 effects in dichloromethane are included for a part of the calculations 652 with the CPCM. ${ }^{45}$

\section{ASSOCIATED CONTENT}

\section{S Supporting Information}

655 The Supporting Information is available free of charge on the 656 ACS Publications website at DOI: 10.1021/acs.inorg657 chem.6b02809.

658

Crystallographic information, additional spectro-electrochemical information, additional calculated DFT data, ${ }^{1} \mathrm{H},{ }^{13} \mathrm{C}$ and ${ }^{31} \mathrm{P}$ NMR spectra of the new compounds. (PDF) Crystallographic data (CIF) Crystallographic data (CIF)

663

\section{AUTHOR INFORMATION}

\section{${ }_{665}$ Corresponding Authors}

666 *E-mail: f.hartl@reading.ac.uk. (F.H.)

667 *E-mail: chshliu@mail.ccnu.edu.cn. (S.H.L.)

668 ORCID

669 František Hartl: 0000-0002-7013-5360

670 Notes

671 The authors declare no competing financial interest.

672 ORCID, Frantisek Hartl: 0000-0002-7013-5360

\section{$673 \square$ ACKNOWLEDGMENTS}

674 The authors acknowledge financial support from National 675 Natural Science Foundation of China (21272088, 21472059, 676 21402057), the self-determined research funds of the CCNU 677 from the colleges' basic research and operation of MOE 678 (CCNU14A05009, CCNU14F01003), and the Excellent 679 Doctoral Dissertation Cultivation Grant from the Central 680 China Normal University (2015YBYB108, 2016YBZZ040).

\section{$681 \square$ REFERENCES}

682 (1) (a) Ren, T. Diruthenium $\sigma$-alkynyl compounds: a new class of 683 conjugated organometallics. Organometallics 2005, 24, 4854-4870. 684 (b) Qi, H.; Noll, B.; Snider, G. L.; Lu, Y.; Lent, S. S.; Fehlner, T. P.; 685 Gupta, A. Dependence of field switched ordered arrays of dinuclear 686 mixed-valence complexes on the distance between the redox centers 687 and the size of the counterions. J. Am. Chem. Soc. 2005, 127, 15218688 15227. (c) Schwab, P. F. H.; Smith, J. R.; Michl, J. Synthesis and 689 properties of molecular rods. 2. Zig-zag rods. Chem. Rev. 2005, 105, 690 1197-1279. (d) Burgun, A.; Ellis, B. G.; Roisnel, T.; Skelton, B. W.; 691 Bruce, M. I.; Lapinte, C. From molecular wires to molecular resistors: 692 TCNE, a class-III/class-II mixed-valence chemical switch. Organo693 metallics 2014, 33, 4209-4219. (e) Blum, A. S.; Ren, T.; Parish, D. A.; 694 Trammell, S. A.; Moore, M. H.; Kushmerick, J. G.; Xu, G. L.; 695 Deschamps, J. R.; Pollack, S. K.; Shashidhar, R. $\mathrm{Ru}_{2}(\text { ap) })_{4}(\sigma$ 696 oligo(phenyleneethynyl)) molecular wires: synthesis and electronic 697 characterization. J. Am. Chem. Soc. 2005, 127, 10010-10011.

698 (2) (a) Crutchley, R. J. Intervalence charge transfer and electron 699 exchange studies of dinuclear ruthenium complexes. Adv. Inorg. Chem. 700 1994, 41, 273-325. (b) Schwab, P. F. H.; Levin, M. D.; Michl, J. 701 Molecular rods. 1. Simple axial rods. Chem. Rev. 1999, 99, 1863-1933. 702 (c) Xu, G. L.; Crutchley, R. J.; DeRosa, M. C.; Pan, Q. J.; Zhang, H. X.; 703 Wang, X.; Ren, T. Strong electronic couplings between ferrocenyl 704 centers mediated by bis-ethynyl/butadiynyl diruthenium bridges. $J$. 705 Am. Chem. Soc. 2005, 127, 13354-13365. (d) Zhu, X. X.; Ou, Y. P.; 706 Zhang, J.; Xia, J. L.; Yin, J.; Yu, G.-A.; Liu, S. H. Dithia[3.3]707 paracyclophane-based monometal ruthenium acetylide complexes: 708 synthesis, characterization and substituent effects. Dalton Trans. 709 2013, 42, 7177-7189. (e) Xia, J. L.; Man, W. Y.; Zhu, X.; Zhang, 710 C.; Jin, G.; Schauer, P. A.; Fox, M. A.; Yin, J.; Yu, G.; Low, P. J.; Liu, S.
H. Synthesis and characterization of dithia[3.3]paracyclophane- 711 bridged binuclear ruthenium vinyl and alkynyl complexes. Organo- 712 metallics 2012, 31, 5321-5333. (f) Man, W. Y.; Xia, J. L.; Brown, N. J.; 713 Farmer, J. D.; Yufit, D. S.; Howard, J. A. K.; Liu, S. H.; Low, P. J. 714 Spectroscopic and computational studies of the ligand redox non- 715 innocence in mono-and binuclear ruthenium vinyl complexes. 716 Organometallics 2011, 30, 1852-1858. (g) Ou, Y. P.; Zhang, J.; Xu, 717 M.; Xia, J. L.; Hartl, F.; Yin, J.; Yu, G. A.; Liu, S. H. Bridge-localized 718 HOMO-binding character of divinylanthracene-bridged dinuclear 719 ruthenium carbonyl complexes: spectroscopic, spectroelectrochemical, 720 and computational studies. Chem. - Asian J. 2014, 9, 1152-1160. 721 (h) Ou, Y. P.; Zhang, J.; Zhang, F.; Kuang, D.; Hartl, F.; Rao, L.; Liu, 722 S. H. Notable differences between oxidized diruthenium complexes 723 bridged by four isomeric diethynyl benzodithiophene ligands. Dalton 724 Trans. 2016, 45, 6503-6516. (i) Ou, Y. P.; Xia, J. L.; Zhang, J.; Xu, M.; 725 Yin, J.; Yu, G. A.; Liu, S. H. Experimental and theoretical studies of 726 charge delocalization in biruthenium-alkynyl complexes bridged by 727 thiophenes. Chem. - Asian J. 2013, 8, 2023-2032.

(3) (a) Kaim, W. Concepts for metal complex chromophores 729 absorbing in the near infrared. Coord. Chem. Rev. 2011, 255, 2503- 730 2513. (b) Costuas, K.; Rigaut, S. Polynuclear carbon-rich organo- 731 metallic complexes: clarification of the role of the bridging ligand in 732 the redox properties. Dalton Trans. 2011, 40, 5643-5658. (c) Halet, J.- 733 F.; Lapinte, C. Charge delocalization vs localization in carbon-rich iron 734 mixed-valence complexes: A subtle interplay between the carbon 735 spacer and the (dppe) $\mathrm{Cp} * \mathrm{Fe}$ organometallic electrophore. Coord. 736 Chem. Rev. 2013, 257, 1584-1613. (d) Cao, Z.; Xi, B.; Jodoin, D. S.; 737 Zhang, L.; Cummings, S. P.; Gao, Y.; Tyler, S. F.; Fanwick, P. E.; 738 Crutchley, R. J.; Ren, T. Diruthenium-polyyn-diyl-diruthenium 739 wires: electronic coupling in the long distance regime. J. Am. Chem. 740 Soc. 2014, 136, 12174-12183. (e) Brunschwig, B. S.; Creutz, C.; Sutin, 741 N. Electroabsorption spectroscopy of charge transfer states of 742 transition metal complexes. Coord. Chem. Rev. 1998, 177, 61-79. 743 (f) Scheerer, S.; Rotthowe, N.; Abdel-Rahman, O. S.; He, X.; Rigaut, 744 S.; Kvapilová, H.; Winter, R. F.; et al. Vinyl ruthenium-modified 745 biphenyl and 2, 2'-bipyridines. Inorg. Chem. 2015, 54, 3387-3402. 746 (g) Launay, J.-P. Long-distance intervalence electron transfer. Chem. 747 Soc. Rev. 2001, 30, 386-397.

(4) (a) Carroll, R. L.; Gorman, C. B. The genesis of molecular 749 electronics. Angew. Chem., Int. Ed. 2002, 41, 4378-4400. (b) Bennis- 750 ton, A. C. Pushing around electrons: towards 2-D and 3-D molecular 751 switches. Chem. Soc. Rev. 2004, 33, 573-578. (c) Gluyas, J. B. G.; 752 Boden, A. J.; Eaves, S. G.; Yu, H.; Low, P. J. Cross-conjugated systems 753 based on an (E)-hexa-3-en-1,5-diyne-3,4-diyl skeleton: spectroscopic 754 and spectroelectrochemical investigations. Dalton Trans. 2014, 43, 755 6291-6294. (d) Paul, F.; Lapinte, C. Organometallic molecular wires 756 and other nanoscale-sized devices: an approach using the organoiron 757 (dppe)Cp*Fe building block. Coord. Chem. Rev. 1998, 178-180, 431- 758 509. (e) Martin, R. E.; Diederich, F. Lineare monodisperse $\pi$ - 759 konjugierte oligomere: mehr als nur modellverbindungen für 760 polymere. Angew. Chem. 1999, 111, 1440-1469. (f) Martin, R. E.; 761 Diederich, F. Linear monodisperse $\pi$-conjugated oligomers: model 762 compounds for polymers and more. Angew. Chem., Int. Ed. 1999, 38, 763 1350-1377. (g) Yao, C.-J.; Zhong, Y.-W.; Yao, J. N. Charge 764 delocalization in a cyclometalated bisruthenium complex bridged by 765 a noninnocent 1,2,4,5-tetra(2-pyridyl)benzene ligand. J. Am. Chem. 766 Soc. 2011, 133, 15697-15706. (h) Maurer, J.; Sarkar, B.; Schwederski, 767 B.; Kaim, W.; Winter, R. F.; Záliš, S. Divinylphenylene-bridged 768 diruthenium complexes bearing $\mathrm{Ru}(\mathrm{CO}) \mathrm{Cl}\left(\mathrm{P}^{i} \mathrm{Pr}_{3}\right)_{2}$ entities. Organo- 769 metallics 2006, 25, 3701-3712. (i) Pevny, F.; Di Piazza, E.; Norel, L.; 770 Drescher, M.; Winter, R. F.; Rigaut, S. Fully delocalized (ethynyl) 771 (vinyl) phenylene-bridged diruthenium radical complexes. Organo- 772 metallics 2010, 29, 5912-5918.

(5) (a) Whittall, I. R.; McDonagh, A. M.; Humphrey, M. G.; Marek, 774 S. Organometallic complexes in nonlinear optics II: third-order 775 nonlinearities and optical limiting studies. Adv. Organomet. Chem. 776 1999, 43, 349-405. (b) Mayor, M.; von Hänisch, C.; Weber, H. B.; 777 Reichert, J.; Beckmann, D. Ein trans-Platin (II)-Komplex als 778 Einzelmolekülisolator. Angew. Chem. 2002, 114, 1228-1231. 779 
780 (c) Mayor, M.; von Hänisch, C.; Weber, H. B.; Reichert, J.; Beckmann, 781 D. A trans-platinum (II) complex as a single-molecule insulator. 782 Angew. Chem., Int. Ed. 2002, 41, 1183-1186. (d) Schull, T. L.; 783 Kushmerick, J. G.; Patterson, C. H.; George, C.; Moore, M. H.; 784 Pollack, S. K.; Shashidhar, R. Ligand effects on charge transport in 785 platinum (II) acetylides. J. Am. Chem. Soc. 2003, 125, 3202-3203. 786 (e) Pfaff, U.; Hildebrandt, A.; Korb, M.; Lang, H. The influence of an 787 ethynyl spacer on the electronic properties in 2, 5-ferrocenyl788 substituted heterocycles. Polyhedron 2015, 86, 2-9. (f) Miesel, D.; 789 Hildebrandt, A.; Korb, M.; Wild, D. A.; Low, P. J.; Lang, H. Influence 790 of P-bonded bulky substituents on electronic interactions in 791 ferrocenyl-substituted phospholes. Chem. - Eur. J. 2015, 21, 11545792 11559. (g) Gidron, O.; Diskin-Posner, Y.; Bendikov, M. High charge 793 delocalization and conjugation in oligofuran molecular wires. Chem. 794 Eur. J. 2013, 19, 13140-13150.

795 (6) (a) Maurer, J.; Linseis, M.; Sarkar, B.; Schwederski, B.; Niemeyer, 796 M.; Kaim, W.; Záliš, S.; Anson, C.; Zabel, M.; Winter, R. F. Ruthenium 797 complexes with vinyl, styryl, and vinylpyrenyl ligands: A case of non798 innocence in organometallic chemistry. J. Am. Chem. Soc. 2008, 130, 799 259-268. (b) Linseis, M.; Záliš, S.; Zabel, M.; Winter, R. F. 800 Ruthenium stilbenyl and diruthenium distyrylethene complexes: 801 aspects of electron delocalization and electrocatalyzed isomerization 802 of the Z-isomer. J. Am. Chem. Soc. 2012, 134, 16671-16692. (c) Záliš, 803 S.; Winter, R. F.; Kaim, W. Quantum chemical interpretation of redox 804 properties of ruthenium complexes with vinyl and TCNX type non805 innocent ligands. Coord. Chem. Rev. 2010, 254, 1383-1396. 806 (d) Lloveras, V.; Caballero, A.; Tárraga, A.; Velasco, M. D.; 807 Espinosa, A.; Wurst, K.; Evans, D. J.; Vidal-Gancedo, J.; Rovira, C.; 808 Molina, P.; Veciana, J. Synthesis and characterization of radical cations 809 derived from mono- and biferrocenyl-substituted 2-aza-1, 3-buta810 dienes: a study of the influence of an asymmetric and oxidizable bridge 811 on intramolecular electron transfer. Eur. J. Inorg. Chem. 2005, 2005, 812 2436-2450.

813 (7) (a) Creutz, C.; Taube, H. Direct approach to measuring the 814 Franck-Condon barrier to electron transfer between metal ions. J. Am. 815 Chem. Soc. 1969, 91, 3988-3989. (b) Creutz, C.; Taube, H. Binuclear 816 complexes of ruthenium ammines. J. Am. Chem. Soc. 1973, 95, 1086817 1094. (c) Demadis, K. D.; Hartshorn, C. M.; Meyer, T. J. The 818 localized-to-delocalized transition in mixed-valence chemistry. Chem. 819 Rev. 2001, 101, 2655-2686. (d) Nelsen, S. F. "Almost Delocalized" 820 Intervalence Compounds. Chem. - Eur. J. 2000, 6, 581-588. 821 (e) Yamamoto, M.; Onitsuka, K.; Uno, M.; Takahashi, S. Synthesis 822 of enantiopure planar-chiral cyclopentadienyl-ruthenium binuclear 823 complexes bridged by aromatic systems. J. Chem. Soc., Dalton Trans. 824 2002, 1473-1478. (f) Onitsuka, K.; Harada, Y.; Takahashi, S. 825 Synthesis and properties of chiral organometallic polymers with $(R)$ 826 3,3'-diethynyl-1,1'-binaphthyl bridges. Synth. Met. 2009, 159, 982827985 .

828 (8) (a) Tanaka, Y.; Shaw-Taberlet, J. A.; Justaud, F.; Cador, O.; 829 Roisnel, T.; Akita, M.; Hamon, J.-R.; Lapinte, C. Electronic and 830 magnetic couplings in free and $\pi$-coordinated 1,4-diethynylnaphtha831 lene-bridged $[\mathrm{Cp} *(\mathrm{dppe}) \mathrm{Fe}]^{\mathrm{n}+}(\mathrm{n}=0,1)$ units. Organometallics 2009, 832 28, 4656-4669. (b) Low, P. J. Twists and turns: studies of the 833 complexes and properties of bimetallic complexes featuring phenylene 834 ethynylene and related bridging ligands. Coord. Chem. Rev. 2013, 257, 835 1507-1532. (c) Gao, L.-B.; Kan, J.; Fan, Y.; Zhang, L.-Y.; Liu, S.-H.; 836 Chen, Z.-N. Wirelike dinuclear ruthenium complexes connected by 837 bis(ethynyl)oligothiophene. Inorg. Chem. 2007, 46, 5651-5664. 838 (d) Low, P. J. Metal complexes in molecular electronics: progress 839 and possibilities. Dalton Trans. 2005, 2821-2824. (e) Akita, M.; 840 Koike, T. Chemistry of polycarbon species: from clusters to molecular 841 devices. Dalton Trans. 2008, 3523-3530. (f) Ying, J.-W.; Liu, I. P. C.; 842 Xi, B.; Song, Y.; Campana, C.; Zuo, J.-L.; Ren, T. Linear trimer of 843 diruthenium linked by butadiyn-diyl units: a unique electronic wire. 844 Angew. Chem., Int. Ed. 2010, 49, 954-957. (g) Fan, Y.; Zhang, L.-Y.; 845 Dai, F.-R.; Shi, L.-X.; Chen, Z.-N. Preparation, characterization, and 846 photophysical properties of Pt- $\mathrm{M}(\mathrm{M}=\mathrm{Ru}, \mathrm{Re})$ heteronuclear 847 complexes with 1,10-phenanthrolineethynyl ligands. Inorg. Chem. 848 2008, 47, 2811-2819.
(9) (a) Li, D.; Sun, X.; Wang, M.; Yu, H.; Zhou, H.; Wu, J.; Tian, Y. 849 Novel colorimetric detection probe for copper (II) ions based on 850 triphenylamine mixed-valence chromophores bearing prodigious two- 851 photon absorption activity. Sens. Actuators, B 2015, 220, 1006-1016. 852 (b) Rovira, C.; Ruiz-Molina, D.; Elsner, O.; Vidal-Gancedo, J.; 853 Bonvoisin, J.; Launay, J. P.; Veciana, J. Influence of topology on the 854 long-range electron-transfer phenomenon. Chem. - Eur. J. 2001, 7, 855 240-250. (c) Gautier, N.; Dumur, F.; Lloveras, V.; Vidal-Gancedo, J.; 856 Veciana, J.; Rovira, C.; Hudhomme, P. Intramolecular electron transfer 857 mediated by a tetrathiafulvalene bridge in a purely organic mixed- 858 valence system. Angew. Chem. 2003, 115, 2871-2874. (d) Lindeman, 859 S. V.; Rosokha, S. V.; Sun, D.; Kochi, J. K. X-ray structure analysis and 860 the intervalent electron transfer in organic mixed-valence crystals with 861 bridged aromatic cation radicals. J. Am. Chem. Soc. 2002, 124, 843- 862 855. (e) Rosokha, S. V.; Sun, D. L.; Kochi, J. K. Conformation, 863 distance, and connectivity effects on intramolecular electron transfer 864 between phenylene-bridged aromatic redox centers. J. Phys. Chem. A 865 2002, 106, 2283-2292. (f) Bailey, S. E.; Zink, J. I.; Nelsen, S. F. 866 Contributions of symmetric and asymmetric normal coordinates to the 867 intervalence electronic absorption and resonance raman spectra of a 868 strongly coupled p-phenylenediamine radical cation. J. Am. Chem. Soc. 869 2003, 125, 5939-5947.

(10) (a) Nelsen, S. F.; Konradsson, A. E.; Weaver, M. N.; Telo, J. P. 871 Intervalence near-IR spectra of delocalized dinitroaromatic radical 872 anions. J. Am. Chem. Soc. 2003, 125, 12493-12501. (b) Mayor, M.; 873 Büschel, M.; Fromm, K. M.; Lehn, J. M.; Daub, J. Electron transfer 874 through molecular bridges between reducible pentakis(thiophenyl) 875 benzene subunits. Chem. - Eur. J. 2001, 7, 1266-1272. 876 (c) D’Alessandro, D. M.; Topley, A. C.; Davies, M. S.; Keene, F. R. 877 Probing the transition between the localised (Class II) and localized- 878 to-delocalised (Class II-III) regimes by using intervalence charge- 879 transfer solvatochromism in a series of mixed-valence dinuclear 880 ruthenium complexes. Chem. - Eur. J. 2006, 12, 4873-4884.

881

(11) (a) Heckmann, A.; Amthor, S.; Lambert, C. Mulliken-Hush 882 analysis of a bis (triarylamine) mixed-valence system with a $\mathrm{N} \bullet \bullet \bullet N 883$ distance of $28.7 \AA$ A. Chem. Commun. 2006, 42, 2959-2961. (b) Hanss, 884 D.; Walther, M. E.; Wenger, O. S. Importance of covalence, 885 conformational effects and tunneling-barrier heights for long-range 886 electron transfer: insights from dyads with oligo- $p$-phenylene, oligo- $p$ - 887 xylene and oligo-p-dimethoxybenzene bridges. Coord. Chem. Rev. 2010, 888 254, 2584-2592. (c) Banerjee, M.; Shukla, R.; Rathore, R. Synthesis, 889 optical, and electronic properties of soluble poly- $p$-phenylene 890 oligomers as models for molecular wires. J. Am. Chem. Soc. 2009, 891 131, 1780-1786. (d) Garmshausen, Y.; Schwarz, J.; Hildebrandt, J.; 892 Kobin, B.; Pätzel, M.; Hecht, S. Making nonsymmetrical bricks: 893 synthesis of insoluble dipolar sexiphenyls. Org. Lett. 2014, 16, 2838- 894 2841. (e) Miyata, Y.; Nishinaga, T.; Komatsu, K. Synthesis and 895 structural, electronic, and optical properties of oligo(thienylfuran)s in 896 comparison with oligothiophenes and oligofurans. J. Org. Chem. 2005, 897 70, 1147-1153.

898

(12) (a) Polit, W.; Mücke, P.; Wuttke, E.; Exner, T.; Winter, R. F. 899 Charge and spin confinement to the amine site in 3-connected 900 triarylamine vinyl ruthenium conjugates. Organometallics 2013, 32, 901 5461-5472. (b) Dapperheld, S.; Steckhan, E.; Brinkhaus, K. H. G.; 902 Esch, T. Organic electron transfer systems, II substituted triarylamine 903 cation-radical redox systems-synthesis, electrochemical and spectro- 904 scopic properties, Hammet behavior, and suitability as redox catalysts. 905 Chem. Ber. 1991, 124, 2557-2567. (c) Bender, T. P.; Graham, J. F.; 906 Duff, J. M. Effect of substitution on the electrochemical and 907 xerographic properties of triarylamines: correlation to the Hammett 908 parameter of the substituent and calculated HOMO energy level. 909 Chem. Mater. 2001, 13, 4105-4111. (d) Walter, R. I. Substituent 910 effects on the properties of stable aromatic free radicals. The criterion 911 for non-hammett behavior 1. J. Am. Chem. Soc. 1966, 88, 1923-1930. 912 (e) Amthor, S.; Noller, B.; Lambert, C. UV/Vis/NIR spectral 913 properties of triarylamines and their corresponding radical cations. 914 Chem. Phys. 2005, 316, 141-152.

(13) (a) Connelly, N. G.; Geiger, W. E. Chemical redox agents for 916 organometallic chemistry. Chem. Rev. 1996, 96, 877-910. (b) Tang, C. 917 
918 W.; VanSlyke, A. S. Organic electroluminescent diodes. Appl. Phys. 919 Lett. 1987, 51, 913-915. (c) Law, K. Y. Organic photoconductive 920 materials: recent trends and developments. Chem. Rev. 1993, 93, 449921406.

922 (14) (a) Haridas, K. R.; Ostrauskaite, J.; Thelakkat, M.; Heim, M.; 923 Bilke, R.; Haarer, D. Synthesis of low melting hole conductor systems 924 based on triarylamines and application in dye sensitized solar cells. 925 Synth. Met. 2001, 121, 1573-1574. (b) Bacher, E.; Bayerl, M.; Rudati, 926 P.; Reckefuss, N.; Mueller, C. D.; Meerholz, K.; Nuyken, O. Synthesis 927 and characterization of photo-cross-linkable hole-conducting polymers. 928 Macromolecules 2005, 38, 1640-1647. (c) Kido, J.; Kimura, M.; Nagai, $929 \mathrm{~K}$. Multilayer white light-emitting organic electroluminescent device. 930 Science 1995, 267, 1332-1334. (d) Gu, G.; Bulović, V.; Burrows, P. E.; 931 Forrest, S. R.; Thompson, M. E. Transparent organic light emitting 932 devices. Appl. Phys. Lett. 1996, 68, 2606-2608. (e) Cremer, J.; Bauerle, 933 P.; Wienk, M. M.; Janssen, R. A. J. High open-circuit voltage 934 poly(ethynylene bithienylene):fullerene solar cells. Chem. Mater. 2006, 935 18, 5832-5834. (f) Moerner, W. E.; Silence, S. M. Polymeric 936 photorefractive materials. Chem. Rev. 1994, 94, 127-155. (g) Yen, H. 937 J.; Guo, S. M.; Liou, G. S.; Chung, J. C.; Liu, Y. C.; Lu, Y. F.; Zeng, Y. 938 Z. Mixed-valence class I transition and electrochemistry of bis939 (triphenylamine)-based aramids containing isolated ether-linkage. $J$. 940 Polym. Sci., Part A: Polym. Chem. 2011, 49, 3805-3816.

941 (15) (a) Zhou, G.; Baumgarten, M.; Mullen, K. Arylamine942 substituted oligo(ladder-type pentaphenylene)s: electronic communi943 cation between bridged redox centers. J. Am. Chem. Soc. 2007, 129, 944 12211-12221. (b) Lambert, C.; Risko, C.; Coropceanu, V.; Schelter, 945 J.; Amthor, S.; Gruhn, N. E.; Durivage, J. C.; Brédas, J.-L. Electronic 946 coupling in tetraanisylarylenediamine mixed-valence systems: The 947 interplay between bridge energy and geometric factors. J. Am. Chem. 948 Soc. 2005, 127, 8508-8516. (c) Lancaster, K.; Odom, S. A.; Jones, S. 949 C.; Thayumanavan, S.; Marder, S. R.; Brédas, J.-L.; Coropceanu, V.; 950 Barlow, S. Intramolecular electron-transfer rates in mixed-valence 951 triarylamines: measurement by variable-temperature ESR spectroscopy 952 and comparison with optical data. J. Am. Chem. Soc. 2009, 131, 1717953 1723. (d) Seo, E. T.; Nelson, R. F.; Fritsch, J. M.; Marcoux, L. S.; 954 Leedy, D. W.; Adams, R. N. Anodic oxidation pathways of aromatic 955 amines. Electrochemical and electron paramagnetic resonance studies. 956 J. Am. Chem. Soc. 1966, 88, 3498-3503.

957 (16) (a) Hankache, J.; Wenger, O. S. Organic mixed valence. Chem. 958 Rev. 2011, 111, 5138-5178. (b) Ramírez, C. L.; Pegoraro, C. N.; 959 Filevich, O.; Bruttomeso, A.; Etchenique, R.; Parise, A. R. Role of 960 ruthenium oxidation states in ligand-to-ligand charge transfer 961 processes. Inorg. Chem. 2012, 51, 1261-1268. (c) Parthey, M.; 962 Vincent, K. B.; Schauer, M. R. P. A.; Yufit, D. S.; Howard, J. A. K.; 963 Kaupp, M.; Low, P. J.; Renz, M. A Combined computational and 964 spectroelectrochemical study of platinum-bridged bis-triarylamine 965 systems. Inorg. Chem. 2014, 53, 1544-1554. (d) Lambert, C.; 966 Amthor, S.; Schelter, J. From valence trapped to valence delocalized 967 by bridge state modification in bis(triarylamine) radical cations: 968 evaluation of coupling matrix elements in a three-level system. J. Phys. 969 Chem. A 2004, 108, 6474-6486. (e) Seibt, J.; Schaumlöffel, A.; 970 Lambert, C.; Engel, V. Quantum study of the absorption spectroscopy 971 of bis(triarylamine) radical cations. J. Phys. Chem. A 2008, 112, 972 10178-10184. (f) Heckmann, A.; Lambert, C. Organic mixed-valence 973 compounds: a playground for electrons and holes. Angew. Chem., Int. 974 Ed. 2012, 51, 326-392.

975 (17) (a) Huang, C.-Y.; Hsu, C.-Y.; Yang, L.-Y.; Lee, C.-J.; Yang, T.-F.; 976 Hsu, C.-C.; Ke, C.-H.; Su, Y. O. A systematic study of electrochemical 977 and spectral properties for the electronic interactions in porphyrin978 triphenylamine conjugates. Eur. J. Inorg. Chem. 2012, 2012, 1038979 1047. (b) Yao, C.-J.; Zhong, Y.-W.; Yao, J. Five-stage near-infrared 980 electrochromism in electropolymerized films composed of alternating 981 cyclometalated bisruthenium and bis-triarylamine segments. Inorg. 982 Chem. 2013, 52, 10000-10008. (c) Lambert, C.; Nöll, G.; Schelter, J. 983 Bridge-mediated hopping or superexchange electron-transfer processes 984 in bis(triarylamine) systems. Nat. Mater. 2002, 1, 69-73. (d) Low, P. 985 J.; Paterson, M. A.; Puschmann, H.; Goeta, A. E.; Howard, J. A.; 986 Lambert, C.; Cherryman, J. C.; Tackley, D. R.; Leeming, S.; Brown, B.
Crystal, Molecular and electronic structure of $N, N^{\prime}$-diphenyl- $N, N^{\prime}-987$ bis(2,4-dimethylphenyl)-1,1'-biphenyl)-4, $4^{\prime}$-diamine and the corre- 988 sponding radical cation. Chem. - Eur. J. 2004, 10, 83-91. (e) Barlow, 989 S.; Risko, C.; Odom, S. A.; Zheng, S.; Coropceanu, V.; Beverina, L.; 990 Brédas, J.-L.; Marder, S. R. Tuning delocalization in the radical cations 991 of 1,4-bis[4-(diarylamino)styryl]benzenes, 2,5-bis[4-(diarylamino)- 992 styryl] thiophenes, and 2, 5-bis[4-(diarylamino)styryl]pyrroles through 993 substituent effects. J. Am. Chem. Soc. 2012, 134, 10146-10155. 994 (18) (a) Grelaud, G.; Cador, O.; Roisnel, T.; Argouarch, G.; 995 Cifuentes, M. P.; Humphrey, M. G.; Paul, F. Triphenylamine 996 derivatives with para-disposed pendant electron-rich organoiron 997 alkynyl substituents: defining the magnetic interactions in a trinuclear 998 iron (III) trication. Organometallics 2012, 31, 1635-1642. (b) Cui, B.- 999 B.; Tang, J.-H.; Yao, J.-N.; Zhong, Y.-W. A molecular platform for 1000 multistate near-infrared electrochromism and flip-flop, flip-flap-flop, 1001 and ternary memory. Angew. Chem., Int. Ed. 2015, 54, 9192-9197. 1002 (c) Fink, D.; Weibert, B.; Winter, R. F. Redox-active tetraruthenium 1003 metallacycles: reversible release of up to eight electrons resulting in 1004 strong electrochromism. Chem. Commun. 2016, 52, 6103-6106. 1005 (d) Polit, W.; Exner, T.; Wuttke, E.; Winter, R. F. Vinylruthenium- 1006 triarylamine conjugates as electroswitchable polyelectrochromic NIR 1007 dyes. BioInorg. React. Mech. 2012, 8, 85-105. (e) Tang, J.-H.; Shao, J.- 1008 Y.; He, Y.-Q.; Wu, S.-H.; Yao, J.; Zhong, Y.-W. Transition from a 1009 metal-localized mixed-valence compound to a fully delocalized and 1010 bridge-biased electrophore in a ruthenium-amine-ruthenium tricenter 1011 system. Chem. - Eur. J. 2016, 22, 10341. (f) Cheng, H.-C.; Chiu, K. Y.; 1012 Lu, S. H.; Chen, C.-C.; Lee, Y. W.; Yang, T.-F.; Kuo, M. Y.; Chen, P. P. 1013 Y.; Su, Y. O. Linear oligoarylamines: electrochemical, EPR, and 1014 computational studies of their oxidative states. J. Phys. Chem. A 2015, 1015 119, 1933-1942. (g) Onitsuka, K.; Ohara, N.; Takei, F.; Takahashi, S. 1016 Synthesis and redox properties of trinuclear ruthenium-acetylide 1017 complexes with tri(ethynylphenyl)amine bridge. Dalton Trans. 2006, 1018 3693-3698. (h) Grelaud, G.; Cifuentes, M. P.; Schwich, T.; 1019 Argouarch, G.; Petrie, S.; Stranger, R.; Paul, F.; Humphrey, M. G. 1020 Multistate redox-active metalated triarylamines. Eur. J. Inorg. Chem. 1021 2012, 2012, 65-75. (i) Onitsuka, K.; Ohara, N.; Takei, F.; Takahashi, 1022 S. Organoruthenium dendrimers possessing tris(4-ethynylphenyl)- 1023 amine bridges. Organometallics 2008, 27, 25-27.

1024

(19) (a) Paul, F.; Lapinte, C. Organometallic molecular wires and 1025 other nanoscale-sized devices: an approach using the organoiron- 1026 (dppe)Cp*Fe building block. Coord. Chem. Rev. 1998, 178-180, 427- 1027 505. (b) Akita, M.; Tanaka, Y.; Naitoh, C.; Ozawa, T.; Hayashi, N.; 1028 Takeshita, M.; Inagaki, A.; Chung, M.-C. Synthesis of a series of diiron 1029 complexes based on a tetraethynylethene skeleton and related $\mathrm{C}_{6}-1030$ enediyne spacers, $($ dppe $) \mathrm{Cp} * \mathrm{Fe}-\mathrm{C} \equiv \mathrm{CC}(\mathrm{R})=\mathrm{C}(\mathrm{R}) \mathrm{C} \equiv \mathrm{C}-\mathrm{FeCp}{ }_{-}-1031$ (dppe): tunable molecular wires. Organometallics 2006, 25, 5261- 1032 5275. (c) Tanaka, Y.; Inagaki, A.; Akita, M. A photoswitchable 1033 molecular wire with the dithienylethene (DTE) linker, (dppe) $\left(\eta^{5}-1034\right.$ $\left.\mathrm{C}_{5} \mathrm{Me}_{5}\right) \mathrm{Fe}-\mathrm{C} \equiv \mathrm{C}-\mathrm{DTE}-\mathrm{C} \equiv \mathrm{C}-\mathrm{Fe}\left(\eta^{5}-\mathrm{C}_{5} \mathrm{Me}_{5}\right)$ (dppe). Chem. Com- 1035 mun. 2007, 1169-1171. (d) Motoyama, K.; Koike, T.; Akita, M. 1036 Remarkable switching behavior of bimodally stimuli-responsive 1037 photochromic dithienylethenes with redox-active organometallic 1038 attachments. Chem. Commun. 2008, 5812-5814. (e) Matsuura, Y.; 1039 Tanaka, Y.; Akita, M. $p$-Diethynylbenzene-based molecular wires, $\mathrm{Fe}-1040$ $\mathrm{C} \equiv \mathrm{C}-p-\mathrm{C}_{6} \mathrm{H}_{2} \mathrm{X}_{2}-\mathrm{C} \equiv \mathrm{C}-\mathrm{Fe}\left[\mathrm{Fe}=\mathrm{Fe}\left(\eta^{5}-\mathrm{C}_{5} \mathrm{Me}_{5}\right) \quad(\mathrm{dppe})\right]$ : Synthesis, 1041 substituent effects and unexpected formation of benzodifuran complex. 1042 J. Organomet. Chem. 2009, 694, 1840-1847. (f) Hatanaka, T.; Ohki, 1043 Y.; Kamachi, T.; Nakayama, T.; Yoshizawa, K.; Katada, M.; Tatsumi, K. 1044 Naphthalene and anthracene complexes sandwiched by two $\left\{\left(\mathrm{Cp}^{*}\right)-1045\right.$ $\left.\mathrm{Fe}^{\mathrm{I}}\right\}$ fragments: strong electronic coupling between the $\mathrm{Fe}^{\mathrm{I}}$ centers. 1046 Chem. - Asian J. 2012, 7, 1231-1242. (g) Quardokus, R. C.; Lu, Y.; 1047 Wasio, N. A.; Lent, C. S.; Justaud, F.; Lapinte, C.; Kandel, S. A. 1048 Through-bond versus through-space coupling in mixed-valence 1049 molecules: observation of electron localization at the single-molecule 1050 scale. J. Am. Chem. Soc. 2012, 134, 1710-1714. (h) Ghazala, S. I.; Paul, 1051 F.; Toupet, L.; Roisnel, T.; Hapiot, P.; Lapinte, C. Di-organoiron 1052 mixed valent complexes featuring “ $\left(\eta^{2}\right.$-dppe $)\left(\eta^{5}-\mathrm{C}_{5} \mathrm{Me}_{5}\right) \mathrm{Fe}$ ” 1053 endgroups: smooth Class-III to Class-II transition induced by 1054 
1055 successive insertion of 1,4-phenylene units in a butadiyne-diyl bridge. J. $1056 \mathrm{Am}$. Chem. Soc. 2006, 128, 2463-2476.

1057 (20) Makhoul, R.; Sahnoune, H.; Dorcet, V.; Halet, J.-F.; Hamon, J.1058 R.; Lapinte, C. 1,2-diethynylbenzene-bridged [Cp*(dppe)Fe $]^{\mathrm{n}+}$ units: 1059 effect of steric hindrance on the chemical and physical properties. 1060 Organometallics 2015, 34, 3314-3326.

1061 (21) (a) Fox, M. A.; Le Guennic, B.; Roberts, R. L.; Brue, D. A.; 1062 Yufit, D. S.; Howard, J. A. K.; Manca, G.; Halet, J.-F.; Hartl, F.; Low, P. $1063 \mathrm{~J}$. Simultaneous bridge-localized and mixed-valence character in 1064 diruthenium radical cations featuring diethynylaromatic bridging 1065 ligands. J. Am. Chem. Soc. 2011, 133, 18433-18446. (b) Bruce, M. 1066 I.; Low, P. J.; Hartl, F.; Humphrey, P. A.; de Montigny, F.; Jevric, M.; 1067 Lapinte, C.; Perkins, G. J.; Roberts, R. L.; Skelton, B. W.; White, A. H. 1068 Syntheses, structures, some reactions, and electrochemical oxidation of 1069 ferrocenylethynyl complexes of iron, ruthenium, and osmium. 1070 Organometallics 2005, 24, 5241-5255. (c) Bruce, M. I.; Burgun, A.; 1071 Fox, M. A.; Jevric, M.; Low, P. J.; Nicholson, B. K.; Parker, C. R.; 1072 Skelton, B. W.; White, A. H.; Zaitseva, N. N. Some ruthenium 1073 derivatives of penta-1, 4-diyn-3-one. Organometallics 2013, 32, 32861074 3299. (d) Gao, L.-B.; Zhang, L.-Y.; Shi, L.-X.; Chen, Z.-N. Syntheses, 1075 characterization, redox properties, and mixed-valence chemistry of 1076 tetra-and hexanuclear diyndiyl complexes. Organometallics 2005, 24, 1077 1678-1684.

1078 (22) (a) Bruce, M. I.; Hall, B. C.; Kelly, B. D.; Low, P. J.; Skelton, B. 1079 W.; White, A. H. An efficient synthesis of polyynyl and polyynediyl 1080 complexes of ruthenium(II). J. Chem. Soc., Dalton Trans. 1999, 37191081 3728. (b) Bruce, M. I.; Ellis, B. G.; Gaudio, M.; Lapinte, C.; Melino, 1082 G.; Paul, F.; Skelton, B. W.; Smith, M. E.; Toupet, L.; White, A. H. 1083 Preparation, structures and some reactions of novel diynyl complexes 1084 of iron and ruthenium. Dalton Trans. 2004, 1601-1609.

1085 (23) (a) Paul, F.; Ellis, B. G.; Bruce, M. I.; Toupet, L.; Roisnel, T.; 1086 Costuas, K.; Halet, J.-F.; Lapinte, C. Bonding and substituent effects in 1087 electron-rich mononuclear ruthenium $\sigma$-arylacetylides of the formula $1088\left[\left(\eta^{2}\right.\right.$-dppe $\left.)\left(\eta^{5}-\mathrm{C}_{5} \mathrm{Me}_{5}\right) \mathrm{Ru}(\mathrm{C} \equiv \mathrm{C})-1,4-\left(\mathrm{C}_{6} \mathrm{H}_{4}\right) \mathrm{X}\right]\left[\mathrm{PF}_{6}\right]^{\mathrm{n}}(\mathrm{n}=0,1 ; \mathrm{X}=$ $1089 \mathrm{NO}_{2}, \mathrm{CN}, \mathrm{F}, \mathrm{H}, \mathrm{OMe}, \mathrm{NH}_{2}$ ). Organometallics 2006, 25, 649-665. 1090 (b) Gendron, F.; Burgun, A.; Skelton, B. W.; White, A. H.; Roisnel, T.; 1091 Bruce, M. I.; Halet, J.-F.; Lapinte, C.; Costuas, K. Iron and ruthenium $1092 \sigma$-polyynyls of the general formula $\left[\left\{M(\text { dppe }) C p^{*}\right\}-(C \equiv C)_{n}-R\right]^{0 /+}$ $1093(\mathrm{M}=\mathrm{Fe}, \mathrm{Ru})$ : an experimental and theoretical investigation. 1094 Organometallics 2012, 31, 6796-6811. (c) Bruce, M. I.; Costuas, K.; 1095 Davin, T.; Ellis, B. G.; Halet, J. F.; Lapinte, C.; Low, P. J.; Smith, M. E.; 1096 Skelton, B. W.; Toupet, L.; White, A. H. Iron versus Ruthenium: 1097 dramatic changes in electronic structure result from replacement of 1098 one $\mathrm{Fe}$ by $\mathrm{Ru}$ in $[\{\mathrm{Cp} *($ dppe $) \mathrm{Fe}\}-\mathrm{C} \equiv \mathrm{C}-\mathrm{C} \equiv \mathrm{C}-\{\mathrm{Fe}($ dppe $)$ $\left.\left.1099 \mathrm{Cp}^{*}\right\}\right]^{\mathrm{n}+}(\mathrm{n}=0,1,2)$. Organometallics 2005, 24, 3864-3881. 1100 (d) Gauthier, N.; Argouarch, G.; Paul, F.; Toupet, L.; Ladjarafi, A.; 1101 Costuas, K.; Halet, J.-F.; Samoc, M.; Cifuentes, M. P.; Corkery, T. C.; 1102 Humphrey, M. G. Electron-rich iron/ruthenium arylalkynyl complexes 1103 for third-order nonlinear optics: redox-switching between three states. 1104 Chem. - Eur. J. 2011, 17, 5561-5577. (e) Connelly, N. G.; Gamasa, M. 1105 P.; Gimeno, J.; Lapinte, C.; Lastra, E.; Maher, J. P.; Le Narvor, N.; 1106 Rieger, A. L.; Rieger, P. H. 17-Electron alkynyl complexes of 1107 cyclopentadienyliron(III). J. Chem. Soc., Dalton Trans. 1993, 25751108 2578. (f) Bruce, M. I.; Burgun, A.; Gendron, F.; Grelaud, G.; Halet, J.1109 F.; Skelton, B. W. Oxidative Dimerization of arylalkynyl-ruthenium 1110 complexes. Organometallics 2011, 30, 2861-2868. (g) Le Narvor, N.; 1111 Toupet, L.; Lapinte, C. Elemental carbon chain bridging two iron 1112 centers: syntheses and spectroscopic properties of $\left[\mathrm{Cp}^{*}(\mathrm{dppe}) \mathrm{Fe}-\right.$ $\left.1113 \mathrm{C}_{4}-\mathrm{FeCp} *(\mathrm{dppe})\right]^{n+} \bullet n\left[\mathrm{PF}_{6}\right]^{-}$. X-ray crystal structure of the mixed 1114 valence complex $(\mathrm{n}=1)$. J. Am. Chem. Soc. 1995, 117, 7129-7138. 1115 (h) Bruce, M. I.; Ellis, B. G.; Skelton, B. W.; White, A. H. Further 1116 reactions of some bis(vinylidene) diruthenium complexes. J. Organo1117 met. Chem. 2005, 690, 792-801.

1118 (24) (a) Grelaud, G.; Cifuentes, M. P.; Schwich, T.; Argouarch, G.; 1119 Petrie, S.; Stranger, R.; Paul, F.; Humphrey, M. G. Multistate redox1120 active metalated triarylamines. Eur. J. Inorg. Chem. 2012, 2012, 65-75. 1121 (b) Polit, W.; Exner, T.; Wuttke, E.; Winter, R. F. Vinylruthenium1122 triarylamine conjugates as electroswitchable polyelectrochromic NIR 1123 dyes. BioInorg. React. Mech. 2012, 8, 85-105.
(25) (a) Costuas, K.; Cador, O.; Justaud, F.; Le Stang, S.; Paul, F.; 1124 Monari, A.; Evangelisti, S.; Toupet, L.; Lapinte, C.; Halet, J.-F. 3, 5-Bis 1125 (ethynyl) pyridine and 2, 6-bis(ethynyl) pyridine spanning two 1126 $\mathrm{Fe}\left(\mathrm{Cp}^{*}\right)$ (dppe) units: role of the nitrogen atom on the electronic and 1127 magnetic couplings. Inorg. Chem. 2011, 50, 12601-12622. (b) Parthey, 1128 M.; Gluyas, J. B. G.; Schauer, P. A.; Yufit, D. S.; Howard, J. A. K.; 1129 Kaupp, M.; Low, P. J. Refining the interpretation of near-infrared band 1130 shapes in a polyynediyl molecular wire. Chem. - Eur. J. 2013, 19, 9780- 1131 9784. (c) Parthey, M.; Kaupp, M. Quantum-chemical insights into 1132 mixed-valence systems: within and beyond the Robin-Day scheme. 1133 Chem. Soc. Rev. 2014, 43, 5067-5088. (d) Burgun, A.; Gendron, F.; 1134 Sumby, C.; Roisnel, T.; Cador, O.; Costuas, K.; Halet, J.-F.; Bruce, M. 1135 I.; Lapinte, C. Hexatriynediyl chain spanning two Cp*(dppe)M 1136 termini $(\mathrm{M}=\mathrm{Fe}, \mathrm{Ru})$ : evidence for the dependence of electronic and 1137 magnetic couplings on the relative orientation of the termini. 1138 Organometallics 2014, 33, 2613-2627. (e) Makhoul, R.; Kumamoto, 1139 Y.; Miyazaki, A.; Justaud, F.; Gendron, F.; Halet, J.-F.; Hamon, J.-R.; 1140 Lapinte, C. Synthesis and properties of a mixed-valence compound 1141 with single-step tunneling and multiple-step hopping behavior. Eur. J. 1142 Inorg. Chem. 2014, 2014, 3899-3911. (f) Zhang, J.; Zhang, M.-X.; Sun, 1143 C.-F.; Xu, M.; Hartl, F.; Yin, J.; Yu, G.-A.; Rao, L.; Liu, S.-H. 1144 Diruthenium complexes with bridging diethynyl polyaromatic ligands: 1145 synthesis, spectroelectrochemistry, and theoretical calculations. Orga- 1146 nometallics 2015, 34, 3967-3978. (g) Denis, R.; Toupet, L.; Paul, F.; 1147 Lapinte, C. Electron-rich piano-stool iron $\sigma$-acetylides bearing a 1148 functional aryl group. synthesis and characterization of iron (II) and 1149 iron (III) complexes. Organometallics 2000, 19, 4240-4251. 1150

(26) (a) Gauthier, N.; Tchouar, N.; Justaud, F.; Argouarch, G.; 1151 Cifuentes, M. P.; Toupet, L.; Touchard, D.; Halet, J.-F.; Rigaut, S.; 1152 Humphrey, M. G.; Costuas, K.; Paul, F. Bonding and electron 1153 delocalization in ruthenium (III) $\sigma$-arylacetylide radicals [trans- $\mathrm{Cl}\left(\eta^{2}-1154\right.$ dppe $\left.)_{2} \mathrm{RuC} \equiv \mathrm{C}\left(4-\mathrm{C}_{6} \mathrm{H}_{4} \mathrm{X}\right)\right]^{+}\left(\mathrm{X}=\mathrm{NO}_{2}, \mathrm{C}(\mathrm{O}) \mathrm{H}, \mathrm{C}(\mathrm{O}) \mathrm{Me}, \mathrm{F}, \mathrm{H}, 1155\right.$ $\left.\mathrm{OMe}, \mathrm{NMe}_{2}\right)$ : misleading aspects of the ESR anisotropy. Organo- 1156 metallics 2009, 28, 2253-2266. (b) Wuttke, E.; Pevny, F.; Hervault, Y.- 1157 M.; Norel, L.; Drescher, M.; Winter, R. F.; Rigaut, S. Fully delocalized 1158 (ethynyl) (vinyl) phenylene bridged triruthenium complexes in up to 1159 five different oxidation states. Inorg. Chem. 2012, 51, 1902-1915. 1160 (27) (a) Zhang, D.-B.; Wang, J.-Y.; Wen, H.-M.; Chen, Z.-N. 1161 Electrochemical, spectroscopic, and theoretical studies on diethynyl 1162 ligand bridged ruthenium complexes with 1, 3-bis(2-pyridylimino) 1163 isoindolate. Organometallics 2014, 33, 4738-4746. (b) Yao, C.-J.; Nie, 1164 H.-J.; Yang, W.-W.; Yao, J.; Zhong, Y.-W. Combined experimental and 1165 computational study of pyren-2,7-diyl-bridged diruthenium complexes 1166 with various terminal ligands. Inorg. Chem. 2015, 54, 4688-4698. 1167 (c) Fox, M. A.; Roberts, R. L.; Baines, T. E.; Le Guennic, B.; Halet, J.- 1168 F.; Hartl, F.; Yufit, D. S.; Albesa-Jové, D.; Howard, J. A. K.; Low, P. J. 1169 Ruthenium complexes of C,C'-bis (ethynyl) carboranes: an inves- 1170 tigation of electronic interactions mediated by spherical pseudo- 1171 aromatic spacers. J. Am. Chem. Soc. 2008, 130, 3566-3578. 1172 (28) (a) Zhang, J.; Ou, Y.-P.; Xu, M.; Sun, C.-F.; Yin, J.; Yu, G.-A.; 1173 Liu, S. H. Synthesis and characterization of dibenzoheterocycle- 1174 bridged dinuclear ruthenium alkynyl and vinyl complexes. Eur. J. Inorg. 1175 Chem. 2014, 2014, 2941-2951. (b) Khairul, W. M.; Fox, M. A.; 1176 Schauer, P. A.; Yufit, D. S.; Albesa-Jové, D.; Howard, J. A. K.; Low, P. J. 1177 The electronic structures of diruthenium complexes containing an 1178 oligo(phenylene ethynylene) bridging ligand, and some related 1179 molecular structures. Dalton Trans. 2010, 39, 11605-11615. 1180 (c) Armitt, D. J.; Bruce, M. I.; Gaudio, M.; Zaitseva, N. N.; Skelton, 1181 B. W.; White, A. H.; Le Guennic, B.; Halet, J.-F.; Fox, M. A.; Roberts, 1182 R. L.; Hartl, F.; Low, P. J. Some transition metal complexes derived 1183 from mono-and di-ethynyl perfluorobenzenes. Dalton Trans. 2008, 1184 6763-6775. (d) Klein, A.; Lavastre, O.; Fiedler, J. Role of the bridging 1185 arylethynyl ligand in Bi-and trinuclear ruthenium and iron complexes. 1186 Organometallics 2006, 25, 635-643.

1187

(29) Amthor, S.; Noller, B.; Lambert, C. UV/Vis/NIR spectral 1188 properties of triarylamines and their corresponding radical cations. 1189 Chem. Phys. 2005, 316, 141-152.

(30) Weyland, T.; Ledoux, I.; Brasselet, S.; Zyss, J.; Lapinte, C. 1191 Nonlinear optical properties of redox-active mono-, bi-, and trimetallic 1192 
$1193 \sigma$-acetylide complexes connected through a phenyl ring in the $1194 \mathrm{Cp} *$ (dppe)Fe series. An example of electro-switchable NLO response. 1195 Organometallics 2000, 19, 5235-5237.

1196 (31) (a) Lambert, C.; Nöll, G. The class II/III transition in 1197 triarylamine redox systems. J. Am. Chem. Soc. 1999, 121, 8434-8442. 1198 (b) Cheng, H.-C.; Chiu, K. Y.; Lu, S. H.; Chen, C.-C.; Lee, Y. W.; 1199 Yang, T.-F.; Kuo, M. Y.; Chen, P. P.-Y.; Su, Y. O. Linear 1200 oligoarylamines: electrochemical, EPR, and computational studies of 1201 their oxidative states. J. Phys. Chem. A 2015, 119, 1933-1942.

1202 (32) (a) Parthey, M.; Gluyas, J. B. G.; Fox, M. A.; Low, P. J.; Kaupp, $1203 \mathrm{M}$. Mixed-valence ruthenium complexes rotating through a conforma1204 tional robin-day continuum. Chem. - Eur. J. 2014, 20, 6895-6908. 1205 (b) Marqués-González, S.; Parthey, M.; Yufit, D. S.; Howard, J. A. K.; 1206 Kaupp, M.; Low, P. J. Combined spectroscopic and quantum chemical 1207 study of $\left[\text { trans }-\mathrm{Ru}\left(\mathrm{C} \equiv \mathrm{CC}_{6} \mathrm{H}_{4} \mathrm{R}^{1}-4\right)_{2}(\mathrm{dppe})_{2}\right]^{\mathrm{n}+}$ and $[$ trans- $\mathrm{Ru}(\mathrm{C} \equiv$ $\left.\left.1208 \mathrm{CC}_{6} \mathrm{H}_{4} \mathrm{R}^{1}-4\right)\left(\mathrm{C} \equiv \mathrm{CC}_{6} \mathrm{H}_{4} \mathrm{R}^{2}-4\right)(\text { dppe })_{2}\right]^{\mathrm{n}+}(\mathrm{n}=0,1)$ complexes: 1209 interpretations beyond the lowest energy conformer paradigm. 1210 Organometallics 2014, 33, 4947-4963.

1211 (33) (a) Hush, N. S. Intervalence-transfer absorption. Part 2. 1212 Theoretical considerations and spectroscopic data. Prog. Inorg. Chem. 1213 1967, 8, 391-444. (b) Hush, N. S. Distance dependence of electron 1214 transfer rates. Coord. Chem. Rev. 1985, 64, 135-157. (c) Hush, N. S. 1215 Homogeneous and heterogeneous optical and thermal electron 1216 transfer. Electrochim. Acta 1968, 13, 1005-1023.

1217 (34) (a) Hamon, P.; Justaud, F.; Cador, O.; Hapiot, P.; Rigaut, S.; 1218 Toupet, L.; Ouahab, L.; Stueger, H.; Hamon, J.-R.; Lapinte, C. Redox1219 active organometallics: magnetic and electronic couplings through 1220 carbon- silicon hybrid molecular connectors. J. Am. Chem. Soc. 2008, 1221 130, 17372-17383. (b) Paul, F.; Toupet, L.; Thépot, J.-Y.; Costuas, $1222 \mathrm{~K}$.; Halet, J.-F.; Lapinte, C. Electron-rich piano-stool iron $\sigma$-acetylides. 1223 Electronic structures of arylalkynyl iron (III) radical cations. 1224 Organometallics 2005, 24, 5464-5478.

1225 (35) Shi, L. Q.; He, C.; Zhu, D. F.; He, Q. G.; Li, Y.; Chen, Y.; Sun, 1226 Y. X.; Fu, Y. Y.; Wen, D.; Cao, H. M.; Cheng, J. G. High performance 1227 aniline vapor detection based on multi-branched fluorescent triphenyl1228 amine-benzothiadiazole derivatives: branch effect and aggregation 1229 control of the sensing performance. J. Mater. Chem. 2012, 22, 11629123011635

1231 (36) Sirohi, R.; Kim, D. H.; Yu, S.-C.; Lee, S. H. Novel di-anchoring 1232 dye for DSSC by bridging of two mono anchoring dye molecules: a 1233 conformational approach to reduce aggregation. Dyes Pigm. 2012, 92, 1234 1132-1137.

1235 (37) Bruce, M. I.; Ellis, B. G.; Low, P. J.; Skelton, B. W.; White, A. H. 1236 Syntheses, structures, and spectro-electrochemistry of $\left\{\mathrm{Cp}^{*}(\mathrm{PP}) \mathrm{Ru}\right\}$ $1237 \mathrm{C} \equiv \mathrm{CC} \equiv \mathrm{C}\{\mathrm{Ru}(\mathrm{PP}) \mathrm{Cp} *\}(\mathrm{PP}=\mathrm{dppm}, \mathrm{dppe})$ and their mono-and 1238 dications. Organometallics 2003, 22, 3184-3198.

1239 (38) Roger, C.; Hamon, P.; Toupet, L.; Rabaâ, H.; Saillard, J.-Y.; 1240 Hamon, J.-R.; Lapinte, C. Alkyl (pentamethylcyclopentadienyl)(1, 21241 bis (diphenylphosphino)-ethane) iron (III) 17-electron complexes: 1242 synthesis, NMR and magnetic properties, and EHMO calculations. 1243 Organometallics 1991, 10, 1045-1054.

1244 (39) Fang, Z.; Samoc, M.; Webster, R. D.; Samoc, A.; Lai, Y. H. 1245 Triphenylamine derivatized phenylacetylene macrocycle with large 1246 two-photon absorption cross-section. Tetrahedron Lett. 2012, 53, 1247 4885-4888.

1248 (40) Sheldrick, G. M. SHELXS-97, a Program for Crystal Structure 1249 Solution; University of Göttingen: Göttingen, Germany, 1997.

1250 (41) Sheldrick, G. M. SHELXL-97, a Program for Crystal Structure 1251 Refinement; University of Göttingen, Göttingen, Germany, 1997.

1252 (42) Krejčík, M.; Daněk, M.; Hartl, F. Simple construction of an 1253 infrared optically transparent thin-layer electrochemical cell: Applica1254 tions to the redox reactions of ferrocene, $\mathrm{Mn}_{2}(\mathrm{CO})_{10}$ and $\mathrm{Mn}(\mathrm{CO})_{3}$ 1255 (3,5-di-t-butyl-catecholate) ${ }^{-}$. J. Electroanal. Chem. Interfacial Electro1256 chem. 1991, 317, 179-187.

1257 (43) Frisch, M. J.; Trucks, G. W.; Schlegel, H. B.; Scuseria, G. E.; 1258 Robb, M. A.; Cheeseman, J. R.; Scalmani, G.; Barone, V.; Mennucci, 1259 B.; Petersson, G. A.; Nakatsuji, H.; Caricato, M.; Li, X.; Hratchian, H. 1260 P.; Izmaylov, A. F.; Bloino, J.; Zheng, G.; Sonnenberg, J. L.; Hada, M.; 1261 Ehara, M.; Toyota, K.; Fukuda, R.; Hasegawa, J.; Ishida, M.; Nakajima,
T.; Honda, Y.; Kitao, O.; Nakai, H.; Vreven, T.; Montgomery, J. A., Jr.; 1262 Peralta, J. E.; Ogliaro, F.; Bearpark, M.; Heyd, J. J.; Brothers, E.; Kudin, 1263 K. N.; Staroverov, V. N.; Kobayashi, R.; Normand, J.; Raghavachari, K.; 1264 Rendell, A.; Burant, J. C.; Iyengar, S. S.; Tomasi, J.; Cossi, M.; Rega, 1265 N.; Millam, J. M.; Klene, M.; Knox, J. E.; Cross, J. B.; Bakken, V.; 1266 Adamo, C.; Jaramillo, J.; Gomperts, R.; Stratmann, R. E.; Yazyev, O.; 1267 Austin, A. J.; Cammi, R.; Pomelli, C.; Ochterski, J. W.; Martin, R. L.; 1268 Morokuma, K.; Zakrzewski, V. G.; Voth, G. A.; Salvador, P.; 1269 Dannenberg, J. J.; Dapprich, S.; Daniels, A. D.; Farkas, Ö.; 1270 Foresman, J. B.; Ortiz, J. V.; Cioslowski, J.; Fox, D. J. Gaussian 09, 1271 Revision D.01; Gaussian, Inc.: Wallingford, CT, 2009.

1272

(44) Renz, M.; Theilacker, K.; Lambert, C.; Kaupp, M. A reliable 1273 quantum-chemical protocol for the characterization of organic mixed- 1274 valence compounds. J. Am. Chem. Soc. 2009, 131, 16292-16302. 1275

(45) (a) Cossi, M.; Rega, N.; Scalmani, G.; Barone, V. Energies, 1276 structures, and electronic properties of molecules in solution with the 1277 C-PCM solvation model. J. Comput. Chem. 2003, 24, 669-681. 1278 (b) Barone, V.; Cossi, M. Quantum calculation of molecular energies 1279 and energy gradients in solution by a conductor solvent model. J. Phys. 1280 Chem. A 1998, 102, 1995-2001. 